\title{
Microbial Shift in the Enteric Bacteriome of Coral Reef Fish Following Climate-Driven Regime Shifts
}

\author{
Marie-Charlotte Cheutin ${ }^{1, *} \mathbb{1}$, Sébastien Villéger ${ }^{1}$, Christina C. Hicks ${ }^{2}$, James P. W. Robinson ${ }^{2} \mathbb{D}$, \\ Nicholas A. J. Graham ${ }^{2}$, Clémence Marconnet ${ }^{1}$, Claudia Ximena Ortiz Restrepo ${ }^{1}$, Yvan Bettarel ${ }^{1}$, \\ Thierry Bouvier ${ }^{1}$ and Jean-Christophe Auguet ${ }^{1}$ \\ 1 UMR MARBEC, Université de Montpellier, CNRS, Ifremer, IRD, 34095 Montpellier, France; \\ sebastien.villeger@cnrs.fr (S.V.); marconnet.clemence@gmail.com (C.M.); \\ claudiaximenaro@gmail.com (C.X.O.R.); yvan.bettarel@ird.fr (Y.B.); thierry.bouvier@cnrs.fr (T.B.); \\ Jean-christophe.AUGUET@cnrs.fr (J.-C.A.) \\ 2 Lancaster Environment Centre, Lancaster University, Lancaster LA1 4YQ, UK; \\ christina.hicks@lancaster.ac.uk (C.C.H.); james.robinson@lancaster.ac.uk (J.P.W.R.); \\ nick.graham@lancaster.ac.uk (N.A.J.G.) \\ * Correspondence: mccheutin@gmail.com
}

\section{check for} updates

Citation: Cheutin, M.-C.; Villéger, S.; Hicks, C.C.; Robinson, J.P.W.;

Graham, N.A.J.; Marconnet, C.;

Restrepo, C.X.O.; Bettarel, Y.; Bouvier,

T.; Auguet, J.-C. Microbial Shift in the

Enteric Bacteriome of Coral Reef Fish Following Climate-Driven Regime Shifts. Microorganisms 2021, 9, 1711. https://doi.org/10.3390/

microorganisms 9081711

Academic Editor: Ulrich (Uli) Stingl

Received: 13 July 2021

Accepted: 6 August 2021

Published: 11 August 2021

Publisher's Note: MDPI stays neutral with regard to jurisdictional claims in published maps and institutional affiliations.

Copyright: (c) 2021 by the authors. Licensee MDPI, Basel, Switzerland. This article is an open access article distributed under the terms and conditions of the Creative Commons Attribution (CC BY) license (https:// creativecommons.org/licenses/by/ $4.0 /)$.

\begin{abstract}
Replacement of coral by macroalgae in post-disturbance reefs, also called a "coral-macroalgal regime shift", is increasing in response to climate-driven ocean warming. Such ecosystem change is known to impact planktonic and benthic reef microbial communities but few studies have examined the effect on animal microbiota. In order to understand the consequence of coral-macroalgal shifts on the coral reef fish enteric bacteriome, we used a metabarcoding approach to examine the gut bacteriomes of 99 individual fish representing 36 species collected on reefs of the Inner Seychelles islands that, following bleaching, had either recovered to coral domination, or shifted to macroalgae. While the coral-macroalgal shift did not influence the diversity, richness or variability of fish gut bacteriomes, we observed a significant effect on the composition ( $R 2=0.02 ; p=0.001$ ), especially in herbivorous fishes $(\mathrm{R} 2=0.07 ; p=0.001)$. This change is accompanied by a significant increase in the proportion of fermentative bacteria (Rikenella, Akkermensia, Desulfovibrio, Brachyspira) and associated metabolisms (carbohydrates metabolism, DNA replication, and nitrogen metabolism) in relation to the strong turnover of Scarinae and Siganidae fishes. Predominance of fermentative metabolisms in fish found on macroalgal dominated reefs indicates that regime shifts not only affect the taxonomic composition of fish bacteriomes, but also have the potential to affect ecosystem functioning through microbial functions.
\end{abstract}

Keywords: coral-macroalgal shift; coral reef fish; enteric bacteriome; microbial functions; barcoding

\section{Introduction}

Coral reefs have increasingly been subject to critical disturbances leading to a decrease of coral cover [1], a loss of coral habitat biodiversity [2], and to a reduction in associated ecosystem services [3,4]. Among the multiple stressors driving reef ecosystem decline, sea surface warming is responsible for severe bleaching events worldwide and the subsequent mortality of corals. In addition to climatic anomalies, overexploitation of herbivore fishes and nutrient discharges derived from land run-off can reduce coral cover and enhance the proliferation of macroalgae [5,6]. Indeed "coral-macroalgae regime shifts" are frequent in post-disturbance reefs [7,8]. Increase in macroalgal cover affects the resilience of coral reefs by reducing the survival and growth of adult corals [9], and/or preventing the recruitment of juvenile corals [10]. Macroalgae also produce secondary metabolites that can induce the growth of pathogenic and fouling microorganisms, causing a physiological deterioration of the coral tissues [11] and a dysbiosis in their microbiome [12]. This shift is not only dramatic for coral fitness, but it also impacts the assemblage composition and trophic 
structure of the entire coral habitat $[13,14]$ and endangers associated ecosystem services (i.e., protection of coastal communities against storms, provision of protein through reef fisheries, and generation of tourism related incomes) $[3,15,16]$.

Among coral reef biota, fishes play a well-known central role in coral-macroalgae regime shifts since the loss of herbivorous fishes through overfishing is considered as one of the causes of dominance by macroalgae [5]. Changes in composition and abundance of fish assemblages related to coral-macroalgae regime shifts are well understood, leaving gaps in knowledge about the impact of macroalgal dominance on other ecological traits of fishes, such as their microbiota. The great diversity of coral reef fishes, with more than 6000 species described [17], combined with the high diversity of their biological traits, provide specific ecological niches both on their skin and within their bodies, which ultimately promote the development of taxonomically and functionally original microbial lineages compared to the surrounding environment [18,19]. In a recent study, Chiarello et al. (2020) [19] showed with a conservative estimation that coral reef animal microbiota may account for up to $2.5 \%$ of Earth's prokaryotic diversity, representing a hotspot of microbial diversity.

While our understanding of some components of fish microbiota such as viruses, archaea, and protists remain limited, their bacteriome has been more extensively studied in the recent years [18-22]. Most of these bacteria reside in the intestinal tract where they form complex communities and provide a range of essential functions linked to development, immunity, health, protection against pathogen invasion, and even influence behavior [23-25]. However, the most obvious and important role is the contribution of the fish bacteriome to the degradation and assimilation of large and complex molecules [20,26,27]. Evidence has accumulated that the gut bacteriome is not just a random set of microorganisms, but rather a highly variable community depending upon intrinsic fish factors such as diet or genetic background and extrinsic environmental conditions [18,21,22,28,29]. Nonetheless, our understanding of fish bacteriome variability is still scarce compared to terrestrial animals and is even more rare concerning coral reef fishes [30,31]. For example, environmental degradation or modification, such as urban sprawl and captivity, are known to have dramatic consequences on the enteric microbiome by altering the diet of wild animals, and thus impacts host fitness as observed in black howler [32,33] and other vertebrates [34-36]. Whether this impact also takes place in marine animals, and particularly the fish enteric microbiome, is poorly documented. The influence of coral bleaching induced regime shifts on coral reef fish bacteriomes remains unresolved. Furthermore, the loss of the most vulnerable fishes (i.e., corallivores) may induce an erosion of reef prokaryotic richness and their related functions [19]. Such events are clearly case studies to address fish gut microbiome responses and plasticity to environmental degradation. Moreover, understanding which bacterial lineages and associated functions are lost, and if there is compensation by other lineages, it is essential to better understand the consequences of bleaching-induced regime shifts on the functioning of coral reef ecosystems in general.

Coral reefs in Seychelles are located in the northern gyre of the western Indian Ocean (WIO), and are periodically subject to high marine heat waves with extreme SST associated with both El Niño and the Indian Ocean Dipole [37]. Severe bleaching and consequent regime shift events have occurred since the early 1980s [38] with two mass bleaching events in 1998 and 2016 that caused $>90 \%$ and $70 \%$ of cover coral loss, respectively [37,39-41]. Following the 1998 coral bleaching event, Seychelles coral reefs underwent divergent trajectories, either recovering to a live coral condition or undergoing regime shifts to fleshy brown macroalgal dominance [6]. Here, we use these alternate Seychelles coral reef conditions to investigate the consequences of coral-macroalgal phase shift on the diversity and the structure of fish gut bacteriomes. First, we explored the diversity, richness, and composition associated with macroalgae and the enteric coral reef fish core bacteriomes. Second, we assessed the consequences of the regime shifts on the diversity, variability, and composition of the core bacteriomes at both taxonomic and functional levels. 


\section{Materials and Methods}

\subsection{Study Area and Sample Collection}

Seven locations were sampled around Praslin and Mahe islands in January 2019, representing 4 recovering coral reefs (RCR), and 3 macroalgal dominated (mainly Sargassum and green turf algae) reefs (MSR) (Figure 1).

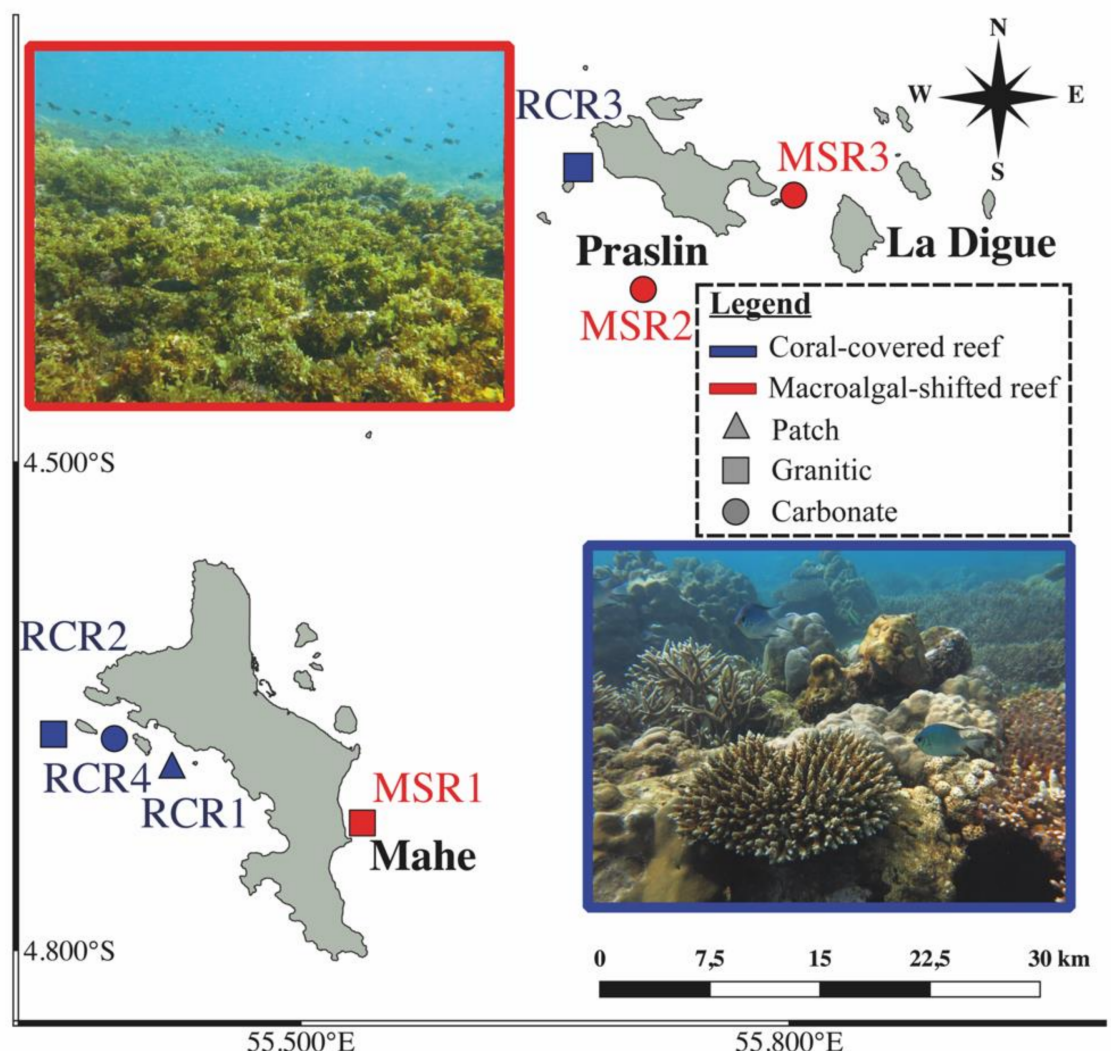

Figure 1. Sampling map of coral-dominated reefs (RCR1: RCR4 in blue) and macroalgae shifted reefs (MSR1: MSR3 in red) with their respective geomorphology (patch, carbonate or granitic). The pictures of coral-covered and macroalgae shifted reefs are represented respectively in blue squared (bottom right) and in red squared (top left). Photo credits: Nicholas A.J. Graham.

The recovering coral reefs had recovered their live coral following the 1998 coral bleaching event [6], but experienced 70\% mortality in 2016, having a mean coral cover of $6 \%$ by 2017 [40]. Reef ecosystems of the Inner Seychelles support ecologically and phylogenetically diverse fish families. Species in the families Siganidae, Lethrinidae, Lutjanidae, Acanthuridae, Scarinae, Mullidae, Labridae, and Haemulidae together comprise $>95 \%$ of total trap fishery catches [42]. Fish samples were collected using handlines and traps deployed from a small boat, using diverse baits (coconut, mackerel, seaweed). In order to take into account intraspecific variability of the gut bacteriome, up to 11 adult individuals of each species were sampled in each site. Immediately after capture, fishes were killed by cervical dislocation (following the European directive 2010/63/UE) and conserved on ice in coolers for dissection in the laboratory later the same day. The animal study was reviewed and approved by the Seychelles Fishing Authority (Memorandum of Understanding signed the 12 December 2018) and by the Lancaster University FST research Ethics review committee (approval number FST18132). At the laboratory (Seychelles Fishing Authority), fishes were placed in trays, washed with $70 \%$ ethanol, and the whole intestinal tract of each fish was extracted using sterile dissection tools following the protocol of Clements et al. (2007) [43] and Miyake et al. (2015) [20]. Briefly, we squeezed out the gut content (taking care to avoid contamination by gut wall cells) into a $2 \mathrm{~mL}$ sterile Eppendorf tube by rolling a sterile $1 \mathrm{~mL}$ micropipette on the intestinal tract starting from segments posterior to the stomach 
(spanning the midgut and hindgut) or from the 75\% most distal part of the gut for fishes lacking stomachs. Gut contents were immediately flash frozen in liquid nitrogen and stored at $-80{ }^{\circ} \mathrm{C}$ until ready for DNA extractions. A total of 99 fishes belonging to 36 species covering 19 genera and 9 families were sampled for their gut bacteriome (Table S1).

\subsection{Fish Identification and Diet Type Definition}

For all fishes, host taxonomic identification was performed using the reference book on reef fishes from the West Indian Sea [44]. Fish diet was described using categories as in Mouillot et al. (2014) [45], where Carnivores are separated into invertivores (MI) which mainly feed on mobile invertebrates (i.e., benthic species such as crustaceans) and piscivores (FC) (i.e., feeding on teleosts or cephalopods). Herbivores are divided into strict herbivores $(\mathrm{H})$ eating fleshy macroalgae with browsing (Siganidae) and grazing (Acanthuridae) behaviors, and detritivores (HD) with scrappers (Scarinae), which bite dead pieces of coral and indirectly scrape away turf algae [46]. Finally, omnivorous fishes (OM) feed on both algae or cyanobacteria and small invertebrates (i.e., zooplankton such as copepods). We used a principal coordinates analysis (PCoA), based on Bray-Curtis dissimilarity, to illustrate their distribution through sampled sites (Figure S1). To assess the sources of variation (i.e., taxonomy and diet) in the Bray-Curtis matrix, we used a PERMANOVA analysis based on 1000 permutations [47] with the function adonis, in the vegan package [48].

\subsection{DNA Extraction and $16 S$ rDNA Gene Amplification}

Total genomic DNA from $200 \mathrm{mg}$ of homogenized intestinal contents and from swabs was extracted using the MagAttract PowerSoil ${ }^{\circledR}$ DNA kit according to the manufacturer instructions (MoBio Laboratories, Inc., Carlsbad, CA, USA) with automated processing and the liquid handling system KingFisher Flex ${ }^{\mathrm{TM}}$ (ThermoScientific ${ }^{\circledR}$, Waltam, MA, USA). Nucleic acids were eluted in molecular water (Merck Millipore ${ }^{\mathrm{TM}}$, Burlington, MA, USA) and quantified on a NanoDrop $8000{ }^{\mathrm{TM}}$ spectrophotometer (ThermoScientific ${ }^{\circledR}$, Wilmington, MA, USA). The V4-V5 region of the 16S rDNA gene was targeted with the universal primers 515F-Y(5'-GTGYCAGCMGCCGCGGTAA-3') and 926R (5'-CCGYCAATTYMTTTRAGT TT-3') [49] coupled with platform specific Illumina adaptor sequences on the $5^{\prime}$ ends. Each $25 \mu \mathrm{L}$ PCR reaction was prepared with $12.5 \mu \mathrm{L}$ Taq Polymerase Phusion ${ }^{\circledR}$ High-Fidelity PCR Master Mix with GC Buffer (New England Biolabs ${ }^{\circledR}$, Inc., Ipswich, MA, USA), $0.5 \mu \mathrm{L}$ forward primer $(10 \mu \mathrm{M}), 0.5 \mu \mathrm{L}$ reverse primer $(10 \mu \mathrm{M}), 1 \mu \mathrm{L}$ template DNA, $0.75 \mu \mathrm{L}$ DMSO, and $9.75 \mu \mathrm{L}$ molecular water. PCR amplifications involved the following protocol: An initial $98^{\circ} \mathrm{C}$ denaturing step for $30 \mathrm{~s}$ following by 35 cycles of amplification (10 s denaturation at $98{ }^{\circ} \mathrm{C} ; 1 \mathrm{~min}$ at $60^{\circ} \mathrm{C}$ annealing; $1.5 \mathrm{~min}$ extension at $72{ }^{\circ} \mathrm{C}$ ), and a final extension of $10 \mathrm{~min}$ at $72^{\circ} \mathrm{C}$. Amplification and primer specificity were verified by electrophoresis on a $2.0 \%$ agarose gel for confirmation of $\sim 450 \mathrm{bp}$ amplicon size. All samples were amplified in triplicate and equally pooled for a final product of $50 \mu \mathrm{L}$. Extraction of blank samples used as DNA extraction controls were also performed. None of them were successfully amplified with the primers used in this study. Each amplicon pool was sequenced using the $2 \times 250$ bp Miseq chemistry on an Illumina MiSeq sequencing platform at the INRA GeT-PlaGE platform (Toulouse, France).

\subsection{Sequence Processing}

All analyses were carried out with R software 3.6.2 (https://www.r-project.org/, accessed on 9 August 2021) [50] and are available on GitHub: https://github.com/ mccheutin/Seychelles.git, accessed on 9 August 2021.

Sequence reads were processed using the DADA2 pipeline (v.1.12.1) in R [51], following the pipeline's tutorial (https:/ / benjjneb.github.io/dada2/tutorial.html, accessed on 9 August 2021). Briefly, sequences were trimmed and filtered based on read quality profiles $(\operatorname{maxN}=0 ; \operatorname{maxEE}=(2,2)$; truncQ $=2$; and truncLen $=(240,240))$, error correct, dereplicated and amplicon sequence variants (ASVs) were inferred [52]. Forward and 
reverse ASVs were merged and pooled in a count table where chimera were identified and removed. Taxonomy assignment was performed using the SILVA reference database (release 132) [53]. The ASVs count table, their taxonomy, and their sequences were organized in a phyloseq object using the phyloseq package (v.1.28.0) [54], on R. ASVs assigned to the kingdom Eukarya, Archaea, and to chloroplast, were removed before computing any further analysis. Bacterial genera known as potential kit contaminants were also removed from our datasets using the list described in Salter et al. (2014) [55]. Overall, 40 genera corresponding to $12 \%$ of the total reads were removed (Supplementary File 1). Our final dataset consisted of 1,042,080 sequences belonging to 5129 ASVs.

\subsection{Defining the Core Bacteriome of Reef Organisms}

As observed in many animal microbiomes [18,56], ASVs may span a range from permanent to transient inhabitants. Closely associated ASVs should be more considered when thinking about holobiont ecology [57] since these core taxa may have evolved in close association with their hosts for a long time period [58-60]. Here, core bacteriomes were independently identified by examining the species abundance distribution (SAD), patterns of each ASV, and by partitioning the SAD into core and satellite ASVs [61] for the gut (Figure S2A) and for the macroalgae (Figure S2B). For this purpose, the index of dispersion for each ASV was calculated as the ratio of the variance to the mean abundance (VMR) multiplied by the occurrence. This index was used to model whether lineages follow a Poisson distribution (i.e., stochastic distribution), falling between the $2.5 \%$ and $97.5 \%$ confidence interval of the $\chi^{2}$ distribution [62]. Index values less than 1 mean that the ASV is under-dispersed compared to the Poisson distribution, so that it spreads uniformly and can be considered as a core ASV. Index values higher than 1 mean that the ASV is over-dispersed, i.e., the ASV is clustered and corresponds to a satellite ASV. Fish and macroalgae core bacteriomes consisted of 531,930 sequences (254 ASVs) and 109,550 sequences (310 ASVs), respectively. All analyses detailed below were performed on the core microbiome.

\subsection{Inference of ASVs Habitat Preference}

We used a BLASTn approach on the $\mathrm{nr} / \mathrm{nt}$ database and the habitat-associated metadata to the closest ASV match to infer the habitat preference of the 254 ASVs constituting the enteric core bacteriome of reef fishes [22,28]. Only blast results with an identity $>95 \%$ and a sequence coverage $>95 \%$ were kept. Information concerning the isolation source contained in the GenBank fields "isolation source", "host", and "title" of each closest blast were extracted using a dedicated python script and parsed into "Animal", "Environment" (i.e., free living bacteria associated with sediment, soil or water), and "Other" habitat categories. For ASVs associated with animals, we further categorized the isolation sources into specific hosts (i.e., fish, marine invertebrates, terrestrial vertebrates, and unknown animals) and organ (i.e., gut, tissue, and other organs) categories (Supplementary File 2). In order to associate these habitat preferences to the phylogenetic affiliation of each ASV, core bacteriome ASVs were aligned against the silva.nr_v132 reference database using mothur v.1.35.1 ([63]; https:/ / mothur.org/, accessed on 9 August 2021) before being imported into the ARB software ([64]; http: / / www.arb-home.de/, accessed on 9 August 2021) and loaded with the SILVA (v.138) reference database [53]. A base frequency filter was applied to exclude highly variable positions before adding sequences to the maximum parsimony backbone tree using the parsimony quick add marked tool implemented in ARB. The tree and the associated categories were drawn and visualized using the interactive Tree of Life (iTOL) web server ([65]; https: / / itol.embl.de/, accessed on 9 August 2021).

\subsection{Computation of Alpha and Beta-Diversity of Bacteriomes}

In order to correct for the uneven sequencing depth among samples, 1041 sequences were randomly sub-sampled within each sample using the "rarefy_even_depth" function from the phyloseq R-package v.1.28 [54] (Figure S3A). Good's coverage estimator [66] was 
$99.9 \pm 0.1$ indicating that the coverage was still excellent after rarefaction. Taxonomic diversity of each microbial community (fish gut or macroalgae swab) was measured using the richness (number of ASV) and the Shannon's index H, computed on ASV relative abundance, and later exponentially transformed to express it as effective number of species (ENS) [67]. Taxonomic dissimilarities between pairs of bacteriome samples were assessed using the Bray-Curtis dissimilarity computed on relative abundances of ASV.

\subsection{Functional Diversity Predictions of Bacteriome}

Using the 16S rRNA gene information, predictions of metabolic functions for Bacteria were performed using Tax4Fun2 v.1.1.5 [68] with a clustering threshold set at 99\%, following the tutorial of the algorithm (https: / /github.com/bwemheu/Tax4Fun2, accessed on 9 August 2021). In order to account for all ASVs, the predicting functional profiles were then proceeded using the minimum blast identity to reference at $78 \%$. Among the 7279 KOs predicted by Tax4Fun2, about $23 \%$ are involved in at least two different metabolic pathways (until 15 for some KOs) and 33\% are unknown or hypothetical proteins. These KOs are thus not indicators of a particular function and are a source of an additional and false functional redundancy, hardly ever taken into account in the literature. To avoid this bias, we created a new functional table containing 3261 unique KOs, involved in only one metabolic pathway.

\subsection{Statistical Tests}

First, the gut and macroalgal bacteriomes were compared in richness and in composition by measuring the alpha and beta-diversity. In the same way, to understand the influence of the reef condition on the bacteriomes, we compared the same measures between reef conditions for both macroalgae and fishes. Since the effect of reef condition could have been masked by the effect of diet or phylogeny, we removed this by analyzing the dataset at different community levels (i.e., inside trophic guilds, family and species level). Only levels with at least a triplicate per reef condition were tested. Comparison of alpha diversity indices (richness and entropy) was achieved using a Kruskal-Wallis test (999 permutations) in the vegan R-package followed by a post-hoc Dunn test (999 perm, $p$-value corrected by Bonferroni's method) in order to identify which group means differed. To determine beta-diversity changes, significant sources of variation in bacteriome Bray-Curtis dissimilarity matrices were assessed using permutational analysis of variance (PERMANOVA) with the adonis function from the vegan package.

ASV biomarkers of bacteriomes of macroalgae, carnivorous, and herbivorous fish were identified using the LEfSe algorithm [69]. The first analysis step was a non-parametric Kruskal-Wallis (KW) sum-rank test allowing the detection of taxa with significant differential abundance. Biological consistency was subsequently investigated using a pairwise Wilcoxon test. Finally, linear discriminant analysis (LDA) was used to estimate the effect size of each differentially abundant taxon. Alpha values of 0.05 were used for KW and Wilcoxon tests and a threshold of 3 was used for logarithmic LDA scores. The same analysis was used to identify functional biomarkers (i.e., KO) of the Scarinae and Siganidae bacteriomes.

\section{Results}

\subsection{Sampling Size and Composition of Fish Catch between Reef Conditions}

The fish species distribution and sample size were highly variable among reefs. The sampling size of caught fish species was higher in recovering coral reefs (RCR), with 27 species sampled compared to 17 species in macroalgae shifted reefs (MSR). Fish community composition and fish diet behavior differed significantly between RCR and MSR (Figure S1A,B) with a higher abundance of the scrapers Scarinae in RCR while grazers Siganidae are more abundant in MSR (Table S1), conforming with the underwater visual census (UVC) data [42]. In contrast, carnivorous species, overall represented by the Lethrinidae and Lutjanidae families, were distributed in both reefs with 11 Lethrinidae in RCR and 15 in 
MSR and six Lutjanidae in RCR and eight in MSR. Only four species have been sampled in triplicate in both RCR and MSR (i.e., Scarus ghobban, Lethrinus mahsena, Lethrinus enigmaticus, and Aprion virescens) (Table S1).

\subsection{Composition and Diversity of the Fish Core Gut Bacteriome}

A total of 254 bacterial ASVs representing 63\% of the total reads formed the core bacteriome of the 99 fish gut samples (Supplementary File 2). This core bacteriome was dominated by the Proteobacteria (dominated by the order Vibrionales) and the Firmicutes phyla (mainly constituted by the order Clostridiales) that represented collectively more than $67 \%$ of the sequences (Figure S4). Other less abundant phyla such as the Bacteroidetes (8\%), Fusobacteria (8\%), Spirochaetes (5\%), Planctomycetes (3\%), Cyanobacteria (3\%), Verrucomicrobia $(3 \%)$, and Tenericutes $(2 \%)$ constituted the rest of the fish core bacteriome.

BLASTn analysis revealed that 70\% (178) of the bacterial ASVs were closely related to sequences previously retrieved from animal microbiomes (Figure 2). In addition, 45\% (115 ASV) belonged to the Akkermansiaceae, Desulfovibrionaceae, Vibrionaceae, Rikenellaceae, Fusobacteriaceae, and Lachnospiraceae families, and matched preferentially sequences previously reported in the intestinal tract of fish from the Siganidae, Acanthuridae, and Scarinae families (Figure 2, Supplementary File 2), indicating a certain degree of conservation for a significant part of the coral fish gut bacteriome.

\begin{tabular}{l} 
Compartment \\
\hline$\square$ Animal \\
$\square$ Environment \\
$\square$ Other \\
Host \\
\hline$\square$ Marine Invertebrates \\
$\square$ Fish \\
$\square$ Terrestrial vertebrates \\
$\square$ Unknown \\
Organ \\
\hline$\square$ Gut \\
$\square$ Tissue \\
$\square$ Other
\end{tabular}

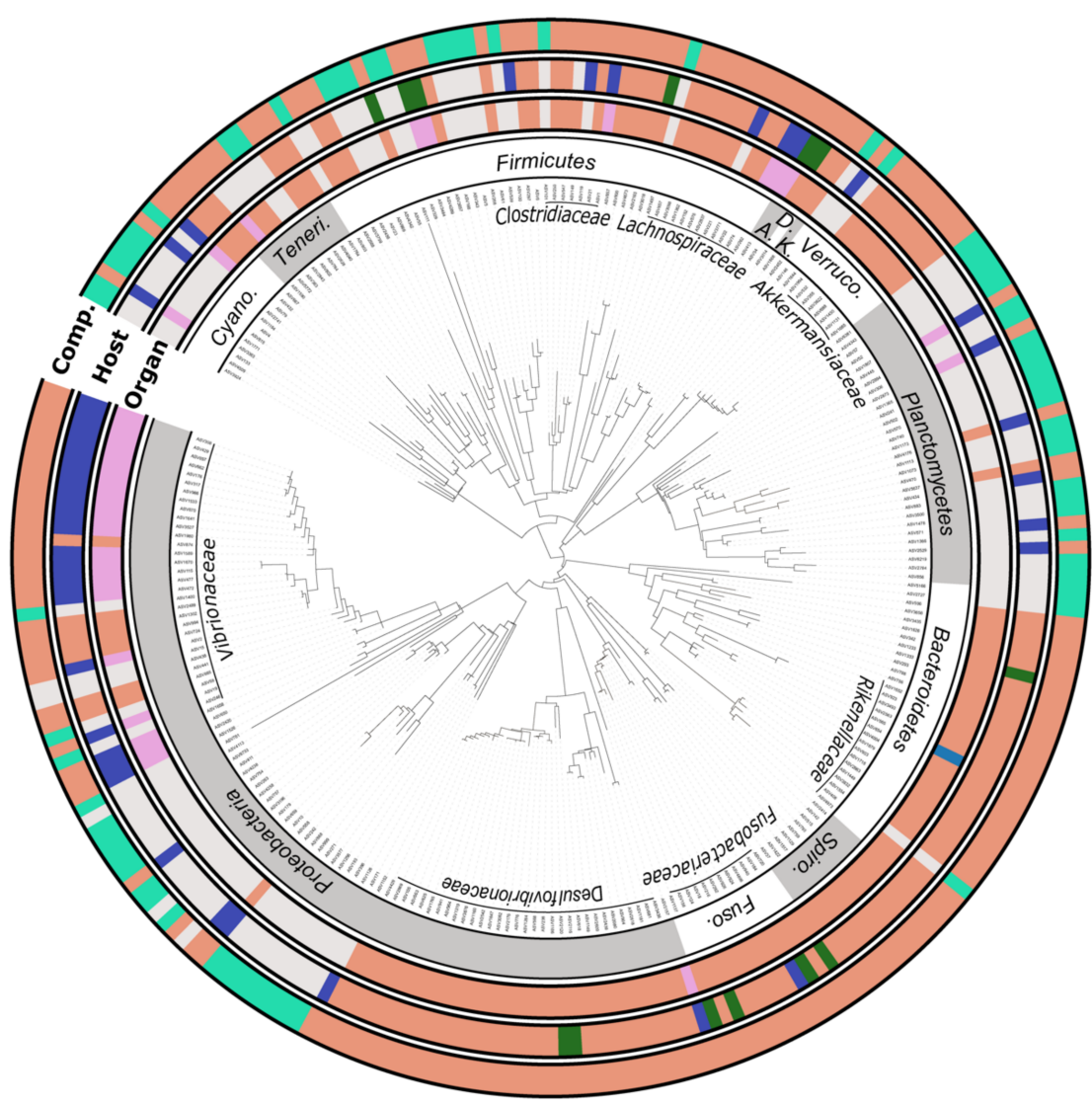

Figure 2. Maximum parsimony phylogenetic tree of the 254 ASVs from the fish gut core bacteriome. The 16S rRNA sequences were inserted into the original SILVA (release 138.1) tree using parsimony criteria with the Bacteria filter excluding highly variable positions. The inner ring represents the order level nomenclature following the taxonomy provided by default in the SILVA bacterial tree. The three outer rings depict the habitat preferences of each ASV described here as three categories (i.e., habitat, specific host, and organ) clustered from the environmental information associated with each closest blast. The tree was drawn using the web-based interface interactive tree of life (iTOL). Abbreviations: Cyano. = Cyanobacteria; Teneri. = Tenericutes; A. = Actinobacteria; D. = Deferribacteres; K. = Kiritimatiellaeota; Verruco. = Verrucomicrobia; Spiro. = Spirochaetes; Fuso. = Fusobacteria . 
In addition to these fish gut specialists, $17 \%$ (44 ASV) of the core ASVs, mainly affiliated to the Vibrionaceae, Pirellulaceae, Lachnospiraceae, and Endozoicomonadaceae families, were best related to sequences associated with other marine animal bacteriomes, such as corals or sponges, indicating that another significant part of the fish gut bacteriome maybe symbiotic generalists distributed among other marine organisms. The composition of fish core gut bacteriomes differed significantly (PERMANOVA $p=0.001$; R2 $=0.07$ ) from macroalgae bacteriomes (Figure S5A) which were dominated by bacteria from the Proteobacteria (56\%), Bacteroidetes (25\%), and Cyanobacteria $(10 \%)$ phyla. Both richness and diversity of fish core gut bacteriomes were half that of macroalgae bacteriomes (Figure S5B). Herbivore bacteriome shared 2.5 times more ASVs with the macroalgal bacteriome than the carnivore one (21 vs. 8) (Figure S6A), mainly belonging to the Orders Bacteroidales (i.e., Rickenella), and Clostridiales (i.e., Lachnoclostridium). Fish gut bacteriomes were also more variable in their composition than macroalgae bacteriomes as indicated by a significantly higher dispersion (Figure S5B).

\subsection{Alteration of the Coral Reef Significantly Disrupts Herbivore but Not Carnivore Bacteriomes}

The reef condition explained a small but significant amount of the variability in bacteriome community composition among all fishes (Table 1; Figure 3A).

Table 1. Results of PERMANOVA on the 29 core bacteriomes of macroalgae and 99 enteric core bacteriomes of reef fish ( $n=$ sampling size). For a relevant sampling size (If not "-"), diet, taxonomy and the reef condition (RCR vs. MSR) were tested (999 perms). Signif. codes for $p$-value: ${ }^{* *} \leq 0.001 ;{ }^{* *} \leq 0.01 ;^{*} \leq 0.05$ or not (NS).

\begin{tabular}{|c|c|c|c|c|c|}
\hline & Diet & Family & Genus & Species & Reef Condition \\
\hline $\begin{array}{c}\text { Algae } \\
(n=29)\end{array}$ & - & - & - & $\begin{array}{c}\mathrm{R} 2=0.13 \\
(* * *)\end{array}$ & $\begin{array}{c}\mathrm{R} 2=0.07 \\
(* *)\end{array}$ \\
\hline $\begin{array}{c}\text { Fish } \\
(n=99)\end{array}$ & $\begin{array}{c}\mathrm{R} 2=0.04 \\
(* * *)\end{array}$ & $\begin{array}{c}\mathrm{R} 2=0.16 \\
(* * *)\end{array}$ & $\begin{array}{c}\mathrm{R} 2=0.27 \\
(* * *)\end{array}$ & $\begin{array}{c}\mathrm{R} 2=0.46 \\
(* * *)\end{array}$ & $\begin{array}{c}\mathrm{R} 2=0.02 \\
(* * *)\end{array}$ \\
\hline $\begin{array}{l}\text { Herbivores } \\
\quad(n=44)\end{array}$ & - & $\begin{array}{c}\mathrm{R} 2=0.14 \\
(* * *)\end{array}$ & $\begin{array}{c}\mathrm{R} 2=0.24 \\
(* * *)\end{array}$ & $\begin{array}{c}\mathrm{R} 2=0.43 \\
(* * *)\end{array}$ & $\begin{array}{c}\mathrm{R} 2=0.07 \\
(* * *)\end{array}$ \\
\hline $\begin{array}{l}\text { Scarinae } \\
(n=22)\end{array}$ & - & - & $\begin{array}{c}\mathrm{R} 2=0.14 \\
(* *)\end{array}$ & - & $\begin{array}{c}\mathrm{R} 2=0.09 \\
(* *)\end{array}$ \\
\hline $\begin{array}{l}\text { S.ghobban } \\
(n=7)\end{array}$ & - & - & - & - & $\begin{array}{c}\mathrm{R} 2=0.28 \\
\text { (NS.) }\end{array}$ \\
\hline $\begin{array}{c}\text { Siganidae } \\
(n=17)\end{array}$ & - & - & - & $\begin{array}{c}\mathrm{R} 2=0.20 \\
(* *)\end{array}$ & - \\
\hline $\begin{array}{c}\text { Carnivores } \\
(n=53)\end{array}$ & - & $\begin{array}{c}\mathrm{R} 2=0.10 \\
(* *)\end{array}$ & $\begin{array}{c}\mathrm{R} 2=0.24 \\
(* *)\end{array}$ & $\begin{array}{c}\mathrm{R} 2=0.44 \\
(*)\end{array}$ & $\begin{array}{c}\mathrm{R} 2=0.02 \\
\text { (NS.) }\end{array}$ \\
\hline $\begin{array}{l}\text { Lutjanidae } \\
(n=14)\end{array}$ & - & - & $\begin{array}{c}\mathrm{R} 2=0.08 \\
\quad(\mathrm{NS} .)\end{array}$ & $\begin{array}{c}\mathrm{R} 2=0.34 \\
\quad(\mathrm{NS} .)\end{array}$ & $\begin{array}{c}\mathrm{R} 2=0.10 \\
\quad(\mathrm{NS} .)\end{array}$ \\
\hline $\begin{array}{c}\text { A.virescens } \\
(n=7)\end{array}$ & - & - & - & - & $\begin{array}{c}\mathrm{R} 2=0.17 \\
\text { (NS.) }\end{array}$ \\
\hline $\begin{array}{l}\text { Lethrinidae } \\
\quad(n=26)\end{array}$ & - & - & - & $\begin{array}{c}\mathrm{R} 2=0.21 \\
\quad(\mathrm{NS} .)\end{array}$ & $\begin{array}{c}\mathrm{R} 2=0.05 \\
\text { (NS.) }\end{array}$ \\
\hline $\begin{array}{l}\text { L.mahsena } \\
(n=10)\end{array}$ & - & - & - & - & $\begin{array}{c}\mathrm{R} 2=0.12 \\
\text { (NS.) }\end{array}$ \\
\hline $\begin{array}{l}\text { L.enigmaticus } \\
\qquad(n=6)\end{array}$ & - & - & - & - & $\begin{array}{c}\mathrm{R} 2=0.17 \\
\quad(\mathrm{NS} .)\end{array}$ \\
\hline
\end{tabular}


(A)

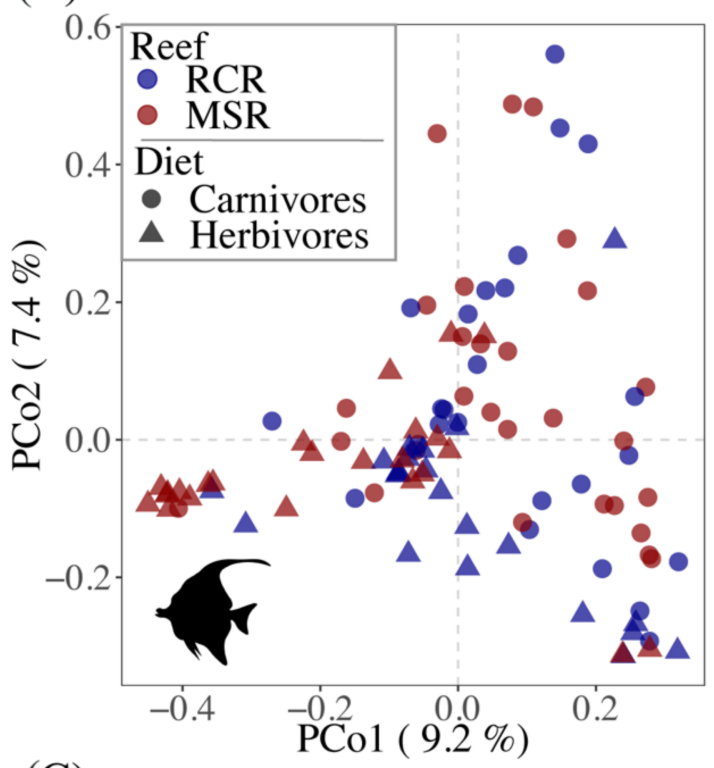

(C)

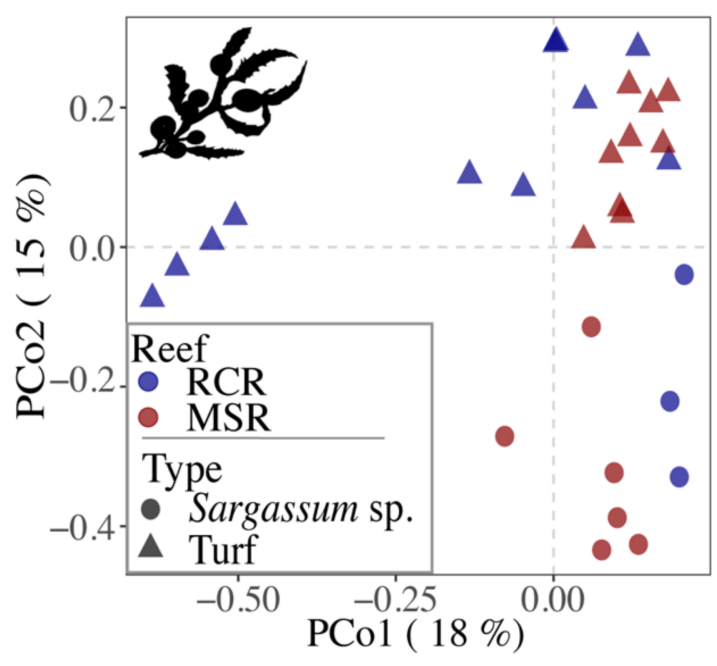

(B)

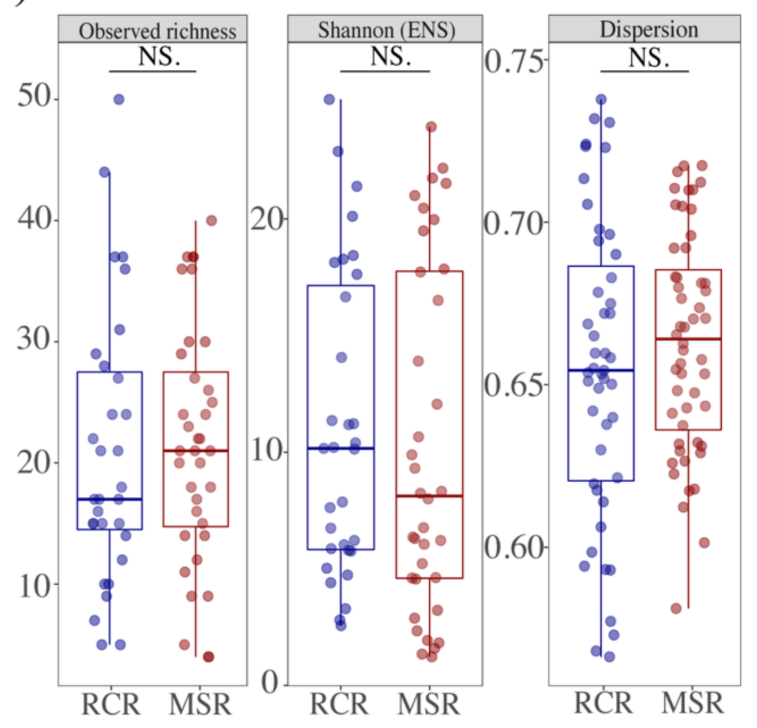

(D)

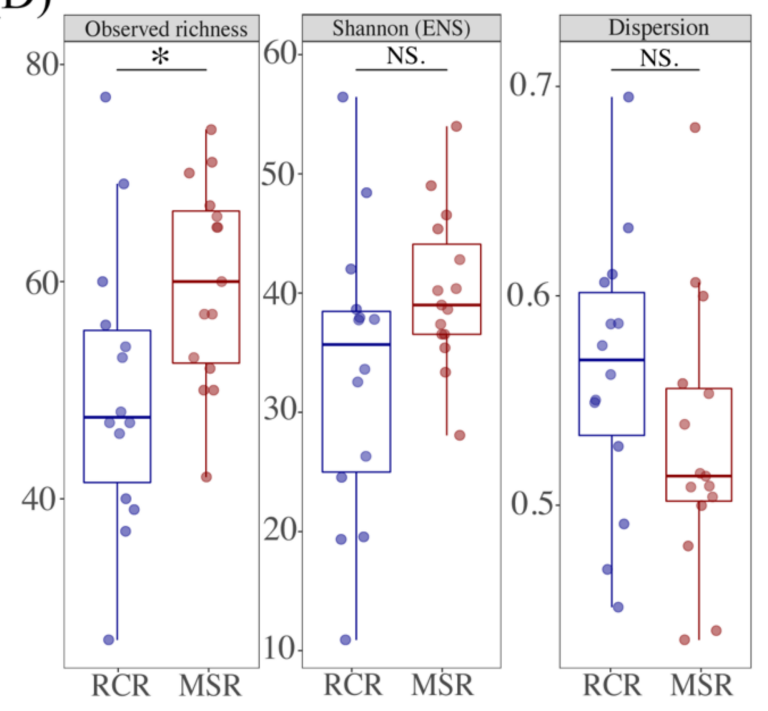

Figure 3. Comparison of the alpha and beta diversity of fish gut and macroalgae bacteriomes in function of the condition of the reef (i.e., coral covered vs. macroalgae shifted). (A,C) Principal coordinates analysis (PCoA) plots illustrating Bray-Curtis distances between pairs of bacteriome samples. Bacteriomes are colored according to the reef condition, while the shape represents (A) fish diet or (C) macroalgae type. (B,D) Boxplots representing the alpha diversity, expressed as the observed richness and the Shannon's index H-exponentially transformed in effective number of species (ENS), and the dispersion (distance to the centroid for each sample type grouping) calculated for each bacteriome sample. Horizontal brackets indicate pairs which differ significantly: ${ }^{* *} \leq 0.001{ }^{* *} \leq 0.01{ }^{*} \leq 0.05$ ) or not (NS) with a Wilcoxon test.

However, the reef condition neither appeared as a significant driver of variability, nor of bacteriome diversity between fish individuals (Figure 3B). Similarly, the ordination of macroalgae bacteriomes in a PCoA showed a clear separation between CCR and RCR (Figure 3C) which explained $7 \%$ of the variance in the community composition for macroalgae bacteriomes (Table 1). In addition, richness of macroalgae bacteriomes were $80 \%$ higher in MSR (Figure 3D). For fishes, diet was one of the main drivers of gut bacteriome composition as indicated by a PERMANOVA analysis (Table 1, Figure 3A). The gut bacteriome of herbivores (i.e., grazers, scrapers, browsers, and the two omnivorous Cantherines pardalis) was characterized by the enrichment of 12 biomarkers, genera belonging mainly to the Desulfovibrionales, Bacteroidales, and Fusobacteriales, while eight genera belonging mainly 
to the Clostridiales and Vibrionales appeared as biomarkers for carnivores (i.e., invertivores and piscivores) (Figure S6B).

The reef condition significantly affected the composition of gut bacteriome of herbivorous fishes $(\mathrm{R} 2=0.07 ; p=0.001$, Figure 4 , Table 1$)$.

(A)

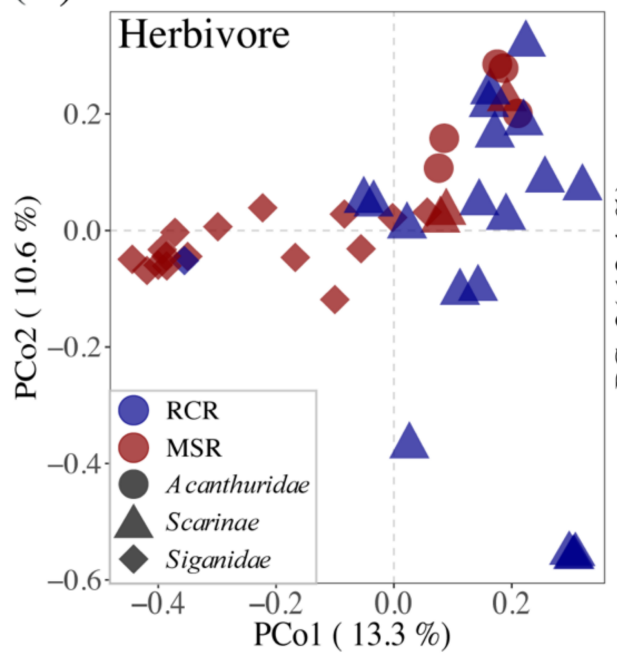

(D)

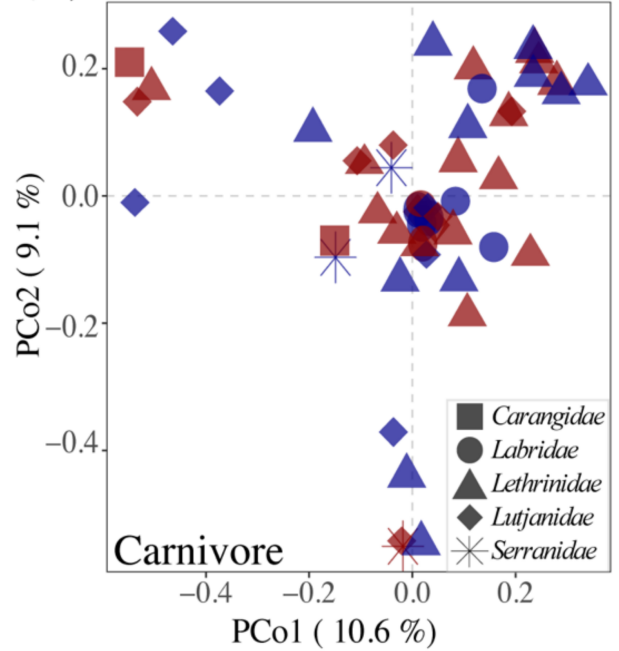

(B)

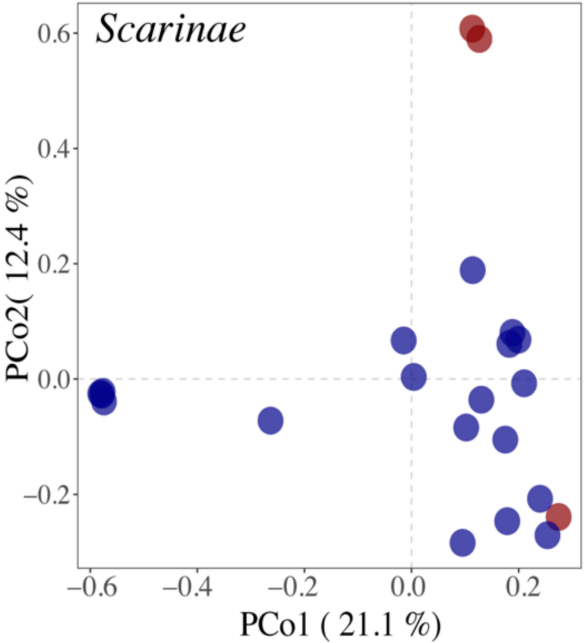

(E)

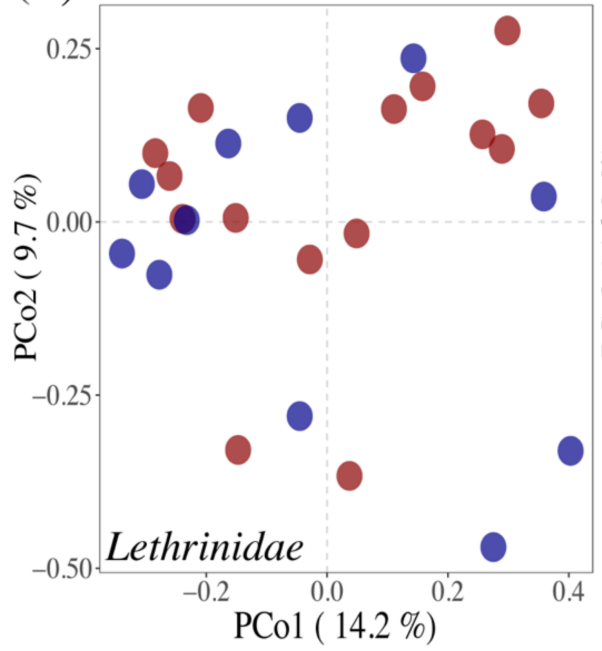

(C)

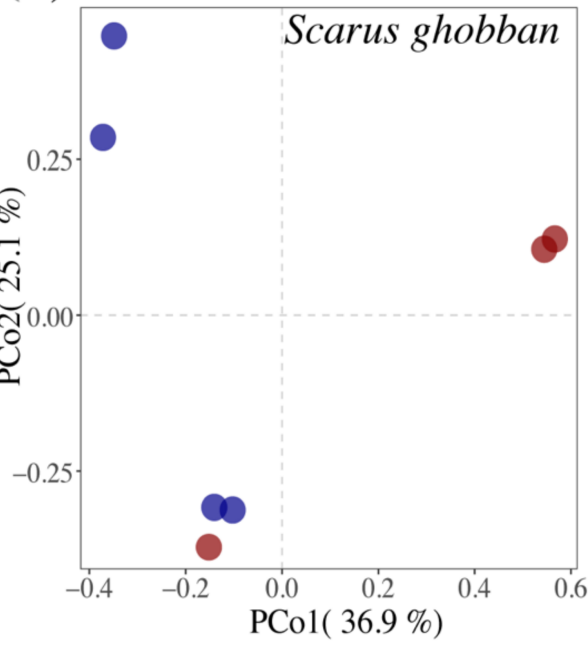

(F)

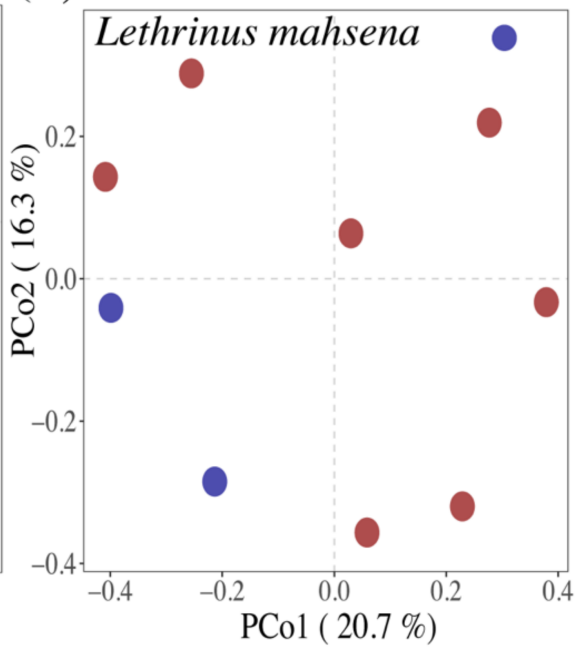

Figure 4. Principal coordinates analysis (PCoA) plots illustrating Bray-Curtis distances between pairs of bacteriome for (A) herbivorous fishes, (B) Scarinae, (C) S.ghobban, (D) carnivorous fishes, (E) Lethrinidae, and (F) L. mahsena. Bacteriomes are colored according to the reef condition: RCR in blue and MSR in red. See Figure S6 for the Lutjanidae, A. virescens, and L. enigmaticus results.

However, part of this effect may be driven by the strong fish species turnover among herbivores between coral and macroalgae dominated reefs. Indeed, 16 out of 17 of Siganidae and Acanthuridae fishes were distributed in MSR, while 19 out of 22 Scarinae fishes (mainly represented by Scarus ghobban) were present in RCR (Figure 4A). Fish phylogeny was a strong and significant determinant of bacteriome composition at the family ( $R 2=0.14$; $p=0.001)$, genus $(\mathrm{R} 2=0.24 ; p=0.001)$, and species $(\mathrm{R} 2=0.43 ; p=0.001)$ levels. In order to exclude this effect, we analyzed the herbivore dataset at the family and species levels (for Scarinae and Scarus ghobban, the only herbivores distributed in both reef conditions). In this way, we corroborated the fact that gut bacteriome composition did differ as a result of reef condition (Figure $4 \mathrm{~B}, \mathrm{C}$ ). This effect was marginal at the species level probably due to the low number of samples ( $\mathrm{R} 2=0.28 ; p=0.078, \mathrm{~N}=7$ ). Differences in the composition of 
herbivore core bacteriomes among reef conditions was driven by changes in the relative abundance of biomarkers of the Scarinae and Siganidae families (Figure 5).

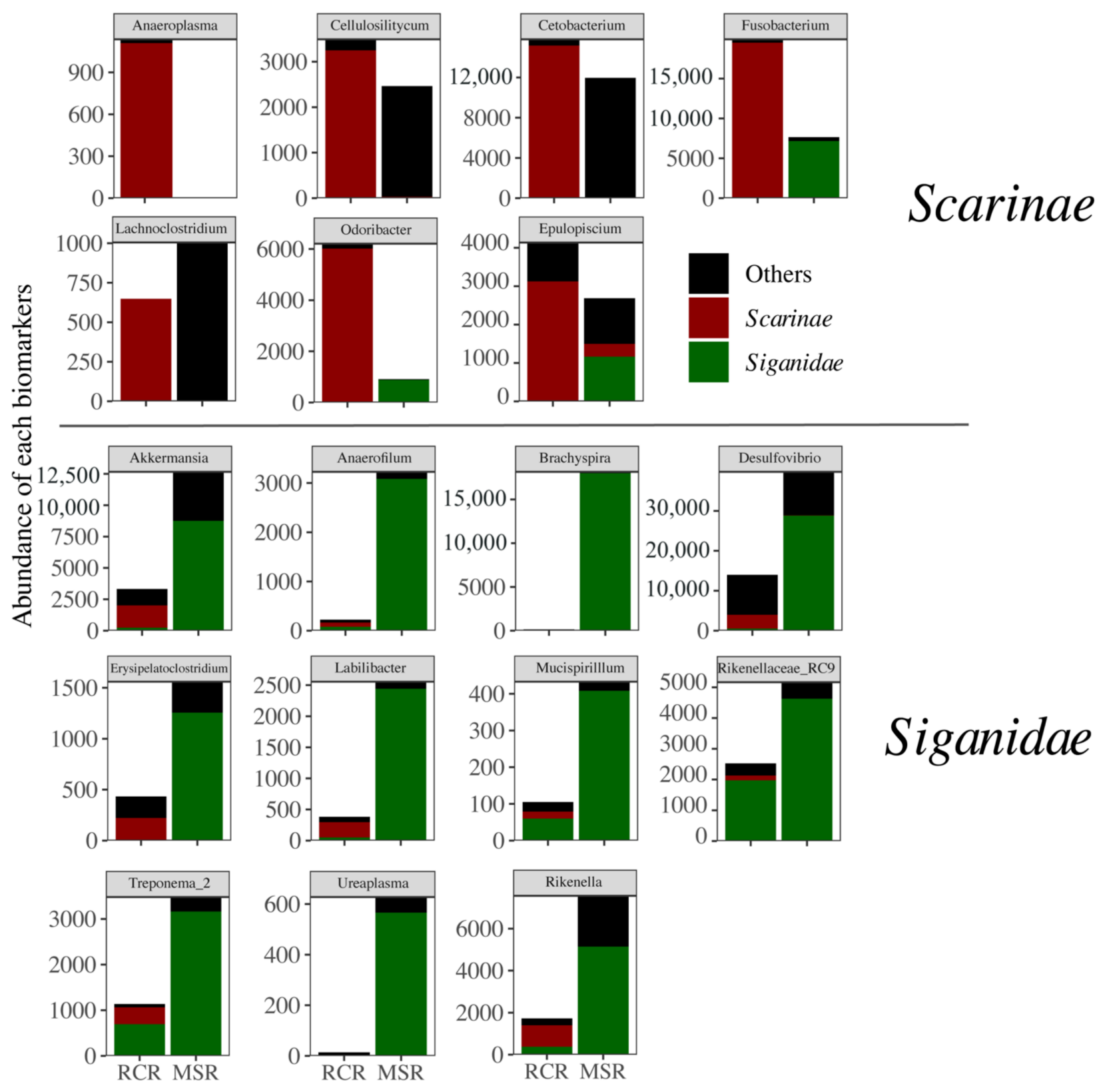

Biomarkers

Figure 5. Abundance of each biomarker at Genus level related to Scarinae and Siganidae (delineated using a LEFSE approach) in RCR and MSR. Contribution of Scarinae (red), Siganidae (green), and other fish families (black) is indicated on each biomarker.

Bacteriome abundance in MSR was lower for six of the seven Scarinae biomarkers and one (i.e., Anaeroplasma) was totally absent. Fusobacterium and Odoribacter biomarkers were only present in Siganidae in MSR (Figure 5). These biomarkers accounted for $0.8 \%$ on average of the Scarinae bacteriomes and $0.4 \%$ of the whole dataset. The decrease in Scarinae biomarkers was paralleled by a significant decrease in the abundance of 207 specific KOs (Kegg Orthologs) mainly involved in host lipid (i.e., fatty acids, butanoate, propanoate, and glycerophospholipid metabolisms) and glucose homeostasis (Figure 6). 


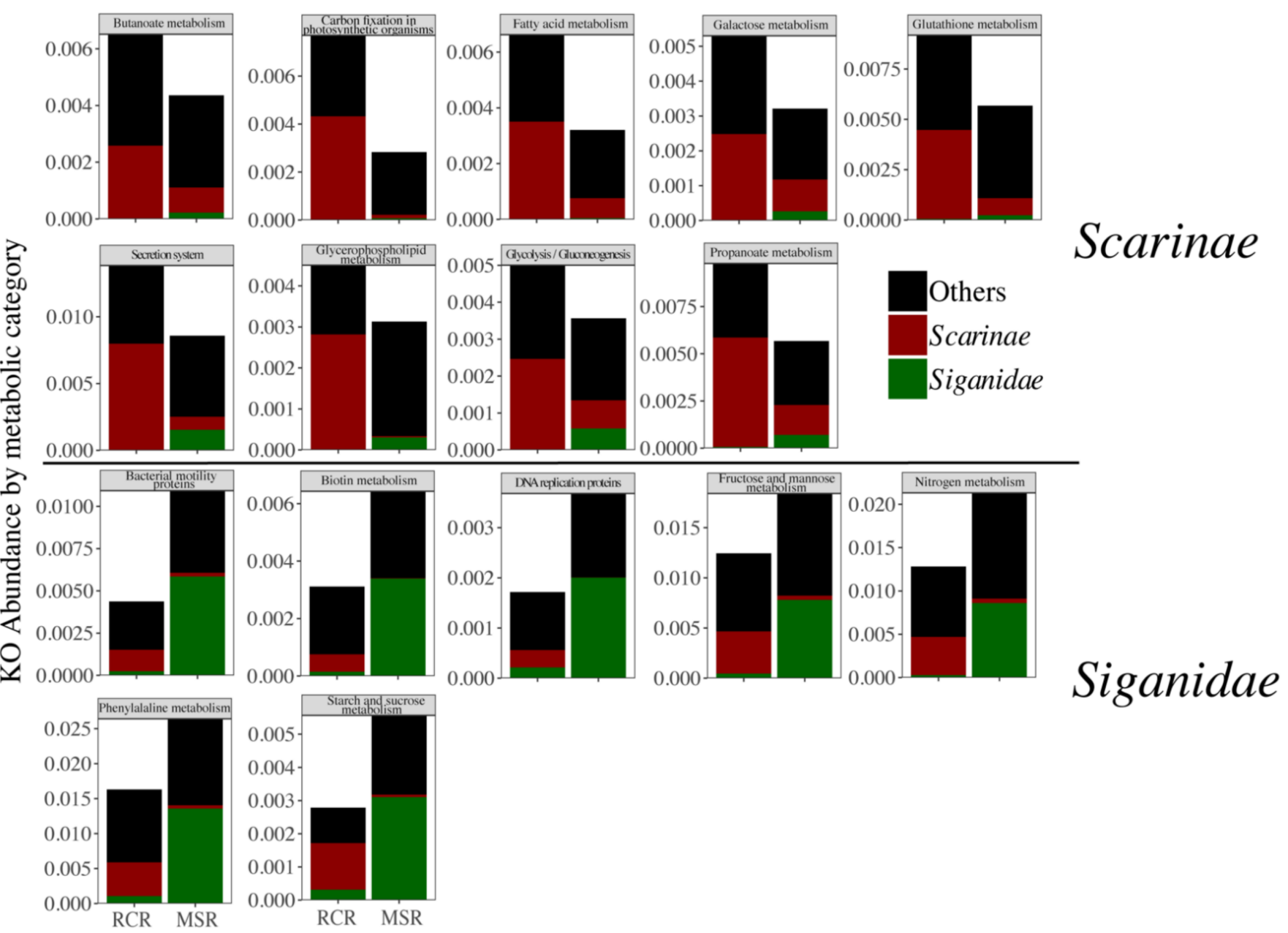

Figure 6. Abundance of each Kegg Ortholog (KO) merged by metabolic pathway, related to enteric bacteriomes of Scarinae (red), Siganidae (green), and other fish families (black) (delineated using a LEfSe approach) in RCR and MSR.

In contrast, Siganidae biomarkers, all efficient anaerobes fermenters of plant and algal polysaccharides [30], showed a significant increase in MSR and one new appeared (i.e., Brachyspira), accounting for $5.9 \%$ on average of the Siganidae bacteriomes and $2.0 \%$ of the whole dataset. This increase came also with an increase in KOs notably involved in carbohydrates metabolism (starch, sucrose, fructose, and mannose), DNA replication, and nitrogen metabolism suggesting higher rates of fermentation and a stimulation of bacterial growth (Figure 6). Reef condition neither appeared as a significant driver of herbivore bacteriome variability, nor of bacteriome diversity (Figure S7).

Contrary to herbivores, we did not detect a significant effect of reef condition on any of the bacteriome diversity facets (i.e., alpha diversity, beta diversity, and variability) of carnivorous fishes (Table 1, Figure 4, Figure S8). The fish family was the only driver of difference in microbiome composition $(\mathrm{R} 2=0.10 ; p=0.007)$.

\section{Discussion}

Macroalgal shifted reefs (MSR) are often considered degraded systems in which drastic changes to biotic communities occur, particularly reef fishes [70,71]. So far, the "microbial phase shift" [72] consecutive to a macroalgae regime shift has been studied only in free living microbial communities [73-76] and primary producer microbiomes [11,77,78]. Here, we pinpointed for the first time the influence of such a shift on the gut bacteriomes of Seychelles reef fishes.

The observations from Robinson et al. (2019) [42] indicated that biodiversity losses were more severe in shifted-reefs resulting in novel fish compositions. This conformed 
with the different fish functions (e.g., browsing and grazing activities) found in MSR compared to recovering coral reefs (RCR) (Figure S1). Alterations to habitat directly affect coral-dependent fish species [79] such as coral dwellers [80,81] and corallivores [82], and promote the replacement of these highly specialized species by opportunistic species that live in areas of low relief and rubble [70,83-85]. In agreement, fish communities from MSR were characterized by a depletion in Scarinae, which are scavengers feeding the epilithic layers present on corals [46], and the dominance of browsers and grazers of the Siganidae and Acanthuridae families [20] (Figure S1, Table S1). By conditioning the availability of their nutritional resources, regime shifts influenced the occurrence of these two herbivorous fish families (Table S1). Among opportunistic species, invertivorous fishes are believed to benefit from a carbon flow cascade in which the important release of dissolved organic material in algae-dominated reefs stimulates microbial production ultimately fueling benthic invertebrate biomass [86,87]. In this study, invertivores, essentially represented by fishes from the Lutjanidae and Lethrinidae families, were however uniformly distributed among RCR and MSR.

Several lines of evidence indicate that microorganisms play an active role in the transition from coral dominance to fleshy algae through the DDAM positive feedback loop (dissolved organic carbon, disease, algae, microorganism) [88,89]. In this mechanism, exudation of labile organic matter by turf and macroalgae promotes an increase in microbial abundance and activity, as well as a change in the composition towards copiotrophic and potentially pathogenic microbial taxa, ultimately causing a physiological deterioration of the coral tissues [11] and a dysbiosis in their microbiome [90]. Except for a recent study [91], disruption of the planktonic microbial composition [73,75,76,92,93] and coral microbiomes $[11,12,77,78,90]$ is a recurrent pattern in MSR. Accordingly, we observed here a significant difference in the composition of macroalgae bacteriomes between MSR and RCR accompanied with an increase in bacterial richness in MSR (Figure 3C,D). Macroalgae bacteriomes in MSR were enriched in Alphaproteobacteria (Ahrensia sp. and Albimonas sp.) and Gammaproteobacteria (Leucothrix sp.). Enrichment in Gammaproteobacteria and particularly from the Leucothrix genera, which contains filamentous species known to provoke massive invertebrate egg and larvae mortalities [94], agrees with the DDAM model predicting that a proliferation of macroalgae leads to an increase in copiotrophic microorganisms with the potential to create disease. Altogether, these results indicate a microbialization [75] of the MSR studied here, although we did not assess microbial abundance in our sampling.

We showed that $45 \%$ of the ASVs composing the core fish gut bacteriomes corresponded to fish specialists, mainly belonging to the Desulfovibrionaceae, Vibrionaceae, Akkermansiaceae, Fusobacteriaceae, and Lachnospiraceae families, often retrieved in studies investigating the gut microbiome of coral fishes [21,22,28,30,95,96]. In addition, a significant part of core ASVs were symbiotic generalists shared among marine organisms indicating a potentially important connectivity of fish gut bacteriomes with their surrounding habitat and animal-associated microbial communities, through feeding activity and defecation. This suggests that perturbations of their habitat microbiome related to macroalgal regime shifts could translocate to their own microbiome. Indeed, although fish diet and taxonomy were major determinants of fish gut bacteriome composition, this latter differed significantly between RCR and MSR (Table 1, Figure 4). Shifts in the fish gut microbiome may reflect changes in diet in degraded habitats. While this has never been observed before in coral reef ecosystems, in disturbed continental areas where their nutritional resources were modified or even absent, the composition of black howler monkey enteric microbiomes responded to habitat perturbations [32,97]. Since macroalgae regime shifts represent an important modification of their main nutritional resources, we hypothesized a strong effect on herbivorous fish gut bacteriomes. In agreement, the reef condition explained a significant amount of the variance for herbivorous fish, while we failed to detect any significant effect for carnivorous fishes. One explanation may be related to the fact that carnivorous fishes seem to have a larger dietary niche width than obligate herbivores [98] that would allow them to forage in adjacent healthy areas of the reef [99]. Our sampling strategy did 
not allow us to detect a significant effect of coral-macroalgal shift at the intra-species level. To overcome this limitation related to the high intra-specific variability observed in fish gut bacteriomes, future investigations should focus on species present in both MSR and CCR and with a significant increase in the number of individuals (more than 10) in each condition and species.

Rather than a dysbiosis, the significant response of herbivorous gut bacteriome composition to the condition of the reef reflected the loss or gain of specific bacterial taxa associated with the strong turnover of their hosts, particularly Scarinae and Siganidae fishes, between RCR and MSR (Figure 6). This result indicates a certain degree of conservation for a significant part of the coral reef fish gut bacteriome, but also agrees with a recent study showing that loss of the most vulnerable reef animals, and among them fishes, due to reef degradation would induce a significant loss of the reef prokaryotic richness [19]. While we did not observe an erosion of bacteriome diversity in MSR, nor an increase of bacteriome variability among individuals expected under the Anna Karenina principle [100], we did record a significant reduction or loss of Scarinae biomarkers and associated functional genes towards the prevalence of bacterial fermenters associated with Siganidae. In addition, we also observed a concomitant increase in abundance of KOs involved in carbohydrate metabolism (starch, sucrose, fructose, and mannose), DNA replication, and nitrogen metabolism, suggesting higher rates of fermentation and a stimulation of bacterial growth in MSR. Seaweeds such as Sargassum and turf algae are rich in sulfated polysaccharides and high carbohydrate food is well known to promote rates of gastrointestinal fermentation [101]. ASVs constituting Siganidae biomarkers were closely related to sequences previously retrieved from Siganus canaliculatus (Supplementary File 2). Indeed, bacteria from the genera Desulfovibrio (sulfate reducing bacteria), Rickenella, Brachyspira (anaerobic fermentative bacteria), and Akkermansia (mucin degrading bacteria) were found to be part of the core bacteriome of Siganidae [102,103], accounting for $5.9 \%$ on average of their bacteriomes and $2.0 \%$ of the whole dataset. These taxa may be of importance for host digestive function in MSR, in particular for the fermentation of sulfated algal polysaccharides. For example, members of the Rikenella genus are known to degrade celluloses into short chain fatty acids (SCFA) available for the host through microbial fermentation $[30,104]$. The prevalence of these fermentative bacteria is in line with the high fermentation rates observed within herbivorous fish hindguts [105], particularly in Siganidae [106] and further suggest a well-suited adaptation of Siganidae bacteriomes to the consumption of algae. We acknowledge that these predicted functions based on barcoding data should be corroborated by future transcriptional or proteomic studies that could address the consequence of coral-macroalgal shift on the fermentative activity of microbes associated with reef fish. Nonetheless, the predominance of fermentative metabolisms in MSR indicated that regime shifts not only affect the taxonomic composition of fish bacteriomes, but has the potential to also affect ecosystem functioning through microbial functions.

\section{Conclusions}

Identifying the mechanisms and consequences of bleaching-induced benthic regime shifts for reef microbiota is vital for understanding the resilience of these habitats to changing ocean conditions. Here, we showed that a "microbial phase shift" occurred following a macroalgae regime shift, which was translocated to the gut bacteriome of herbivore reef fishes affecting their composition and potentially their functional role in the reef ecosystem. This response reflected the loss or gain of specific bacterial taxa associated with the strong turnover of their hosts between RCR and MSR. A pattern that maybe reflects a long-term effect of regime shifts. The consequences of increasing recurrence of "coral-macroalgae regime shifts" on reef animal microbiota and reef functioning is an emerging field of reef ecology. Further work should investigate the repercussions of microbiota dysbiosis consecutive to habitat degradation impacts on both host fitness and ecosystem functioning. 
Supplementary Materials: The following are available online at https://www.mdpi.com/article/10 .3390 / microorganisms 9081711 /s1. Figure S1: PCoA illustrating similarity of fish catch composition and diets; Figure S2: Species abundance distribution (SAD) pattern of bacterial ASVs; Figure S3: Rarefaction curves for each fish gut and macroalgae bacteriomes; Figure S4: Treemaps of the constitutive phyla and their representative families; Figure S5: Beta and alpha diversity of fish gut and macroalgae bacteriomes; Figure S6: Venn diagram and polar histogram; Figure S7: Boxplots representing the alpha diversity; Figure S8: PCoA illustrating Bray-Curtis distances between pairs of bacteriome samples from the Lutjanidae, A. virescens, and L. enigmaticus; Table S1: Inventory of collected species; File S1: List of extraction kit contaminants; File S2: Blast results and the taxonomy.

Author Contributions: Conceptualization, M.-C.C., S.V., C.C.H., J.P.W.R., N.A.J.G., T.B. and J.-C.A.; data curation, J.P.W.R.; formal analysis, M.-C.C., C.M., J.-C.A.; funding acquisition, C.C.H., N.A.J.G. and J.-C.A.; investigation, M.-C.C., S.V., T.B. and J.-C.A.; methodology, M.-C.C. and J.-C.A.; project administration, S.V., T.B., J.P.W.R., N.A.J.G. and J.-C.A.; supervision, S.V., T.B. and J.-C.A.; writingoriginal draft, M.-C.C. and J.-C.A.; writing-review and editing, M.-C.C., S.V., C.C.H., J.P.W.R., N.A.J.G., C.X.O.R., Y.B. and T.B. All authors have read and agreed to the published version of the manuscript.

Funding: This project was funded by a grant from the CNRS INSU EC2CO “Microbien" program project BIOMEVO, a grant from the CNRS international emerging actions (IEA) program project FISH $\mu$ BIOM, the Royal Society, and an ERC grant (759457) to Lancaster University. Marie Charlotte Cheutin was supported by a Ph.D grant from the French Ministry of Higher Education and Research.

Institutional Review Board Statement: The study was approved by Lancaster University FST research Ethics review committee (approval number FST18132) and according to the guidelines of the MoU with the Seychelles Fishing Authority (signed the 12 December 2018). An agreement with Seychelles' government over the transport of biological materials was signed with the Lancaster University (signed the 21 December 2019) and issued by UK DEFRA under the project ITMIP19.0048.

Data Availability Statement: Raw Illumina Miseq sequence data for each sample obtained in this study were deposited in the NCBI Sequence Read Archive (SRA) under BioProject accession no. PRJNA674042.

Acknowledgments: We thank the Seychelles Fishing Authority research team for assistance in the field and with sample preparation (Andrew Souffre, Rodney Melanie, Achille Pascal, Marie-Corinne Balett, Stephanie Marie, Clara Belmont) and Nathalie Bodin for assistance with study design and logistics. We are grateful to three trap fishers who provided boat time and fisheries expertise, and assisted with sample collection. We are grateful to the genotoul sequencing platform in Toulouse (Occitanie, France), for providing the MiSeq Illumina sequencing.

Conflicts of Interest: The authors declare that the research was conducted in the absence of any commercial or financial relationships that could be construed as a potential conflict of interest.

\section{References}

1. Hughes, T.P. Climate Change, Human Impacts, and the Resilience of Coral Reefs. Science 2003, 301, 929-933. [CrossRef]

2. Jackson, J.B.C. Ecological extinction and evolution in the brave new ocean. Proc. Natl. Acad. Sci. USA 2008, 105, 11458-11465. [CrossRef] [PubMed]

3. Woodhead, A.J.; Hicks, C.C.; Norström, A.V.; Williams, G.J.; Graham, N.A.J. Coral reef ecosystem services in the Anthropocene. Funct. Ecol. 2019, 33, 1023-1034. [CrossRef]

4. McWilliam, M.; Pratchett, M.S.; Hoogenboom, M.O.; Hughes, T.P. Deficits in functional trait diversity following recovery on coral reefs. Proc. R. Soc. B Biol. Sci. 2020, 287, 20192628. [CrossRef]

5. Mumby, P.J. The impact of exploiting grazers (Scaridae) on the dynamics of Caribbean coral reefs. Ecol. Appl. 2006, 16, 747-769. [CrossRef]

6. Graham, N.A.J.; Jennings, S.; MacNeil, M.A.; Mouillot, D.; Wilson, S.K. Predicting climate-driven regime shifts versus rebound potential in coral reefs. Nature 2015, 518, 94-97. [CrossRef]

7. Norström, A.; Nyström, M.; Lokrantz, J.; Folke, C. Alternative states on coral reefs: Beyond coral-macroalgal phase shifts. Mar. Ecol. Prog. Ser. 2009, 376, 295-306. [CrossRef]

8. Cheal, A.J.; MacNeil, M.A.; Cripps, E.; Emslie, M.J.; Jonker, M.; Schaffelke, B.; Sweatman, H. Coral-macroalgal phase shifts or reef resilience: Links with diversity and functional roles of herbivorous fishes on the Great Barrier Reef. Coral Reefs 2010, 29, 1005-1015. [CrossRef] 
9. McCook, L.; Jompa, J.; Diaz-Pulido, G. Competition between corals and algae on coral reefs: A review of evidence and mechanisms. Coral Reefs 2001, 19, 400-417. [CrossRef]

10. Hughes, T.P.; Rodrigues, M.J.; Bellwood, D.R.; Ceccarelli, D.; Hoegh-Guldberg, O.; McCook, L.; Moltschaniwskyj, N.; Pratchett, M.S.; Steneck, R.S.; Willis, B. Phase Shifts, Herbivory, and the Resilience of Coral Reefs to Climate Change. Curr. Biol. 2007, 17, 360-365. [CrossRef]

11. Morrow, K.M.; Bromhall, K.; Motti, C.A.; Munn, C.B.; Bourne, D.G. Allelochemicals Produced by Brown Macroalgae of the Lobophora Genus Are Active against Coral Larvae and Associated Bacteria, Supporting Pathogenic Shifts to Vibrio Dominance. Appl. Environ. Microbiol. 2017, 83. [CrossRef] [PubMed]

12. Morrow, K.M.; Liles, M.R.; Paul, V.J.; Moss, A.G.; Chadwick, N.E. Bacterial shifts associated with coral-macroalgal competition in the Caribbean Sea. Mar. Ecol. Prog. Ser. 2013, 488, 103-117. [CrossRef]

13. Burkepile, D.E.; Hay, M.E. Herbivore vs. nutrient control of marine primary producers: Context-dependent effects. Ecology 2006, 87, 3128-3139. [CrossRef]

14. Nyström, M.; Graham, N.A.J.; Lokrantz, J.; Norström, A.V. Capturing the cornerstones of coral reef resilience: Linking theory to practice. Coral Reefs 2008, 27, 795-809. [CrossRef]

15. Hughes, T.P.; Barnes, M.L.; Bellwood, D.R.; Cinner, J.E.; Cumming, G.S.; Jackson, J.B.C.; Kleypas, J.; van de Leemput, I.A.; Lough, J.M.; Morrison, T.H.; et al. Coral reefs in the Anthropocene. Nature 2017, 546, 82-90. [CrossRef]

16. Bellwood, D.R.; Pratchett, M.S.; Morrison, T.H.; Gurney, G.G.; Hughes, T.P.; Álvarez-Romero, J.G.; Day, J.C.; Grantham, R.; Grech, A.; Hoey, A.S.; et al. Coral reef conservation in the Anthropocene: Confronting spatial mismatches and prioritizing functions. Biol. Conserv. 2019, 236, 604-615. [CrossRef]

17. Bellwood, D.R.; Hughes, T.P.; Folke, C.; Nyström, M. Confronting the coral reef crisis. Nature 2004, 429, 827-833. [CrossRef] [PubMed]

18. Chiarello, M.; Auguet, J.C.; Bettarel, Y.; Bouvier, C.; Claverie, T.; Graham, N.A.J.; Rieuvilleneuve, F.; Sucré, E.; Bouvier, T.; Villéger, S. Skin microbiome of coral reef fish is highly variable and driven by host phylogeny and diet. Microbiome 2018, 6, 1-14. [CrossRef]

19. Chiarello, M.; Auguet, J.-C.; Graham, N.A.J.; Claverie, T.; Sucré, E.; Bouvier, C.; Rieuvilleneuve, F.; Restrepo-Ortiz, C.X.; Bettarel, Y.; Villéger, S.; et al. Exceptional but vulnerable microbial diversity in coral reef animal surface microbiomes. Proc. R. Soc. B Biol. Sci. 2020, 287, 20200642. [CrossRef] [PubMed]

20. Miyake, S.; Ngugi, D.K.; Stingl, U. Diet strongly influences the gut microbiota of surgeonfishes. Mol. Ecol. 2015, $24,656-672$. [CrossRef] [PubMed]

21. Pratte, Z.A.; Besson, M.; Hollman, R.D.; Stewarta, F.J. The gills of reef fish support a distinct microbiome influenced by hostspecific factors. Appl. Environ. Microbiol. 2018, 84, 1-15. [CrossRef]

22. Scott, J.J.; Adam, T.C.; Duran, A.; Burkepile, D.E.; Rasher, D.B. Intestinal microbes: An axis of functional diversity among large marine consumers. Proc. R. Soc. B Biol. Sci. 2020, 287, 20192367. [CrossRef]

23. Fischbach, M.A.; Segre, J.A. Signaling in Host-Associated Microbial Communities. Cell 2016, 164, 1288-1300. [CrossRef]

24. Li, X.; Zhou, L.; Yu, Y.; Ni, J.; Xu, W.; Yan, Q. Composition of Gut Microbiota in the Gibel Carp (Carassius auratus gibelio) Varies with Host Development. Microb. Ecol. 2017, 74, 239-249. [CrossRef]

25. Piazzon, M.C.; Calduch-Giner, J.A.; Fouz, B.; Estensoro, I.; Simó-Mirabet, P.; Puyalto, M.; Karalazos, V.; Palenzuela, O.; SitjàBobadilla, A.; Pérez-Sánchez, J. Under control: How a dietary additive can restore the gut microbiome and proteomic profile, and improve disease resilience in a marine teleostean fish fed vegetable diets. Microbiome 2017, 5, 164. [CrossRef] [PubMed]

26. Ngugi, D.K.; Miyake, S.; Cahill, M.; Vinu, M.; Hackmann, T.J.; Blom, J.; Tietbohl, M.D.; Berumen, M.L.; Stingl, U. Genomic diversification of giant enteric symbionts reflects host dietary lifestyles. Proc. Natl. Acad. Sci. USA 2017, 114, E7592-E7601. [CrossRef]

27. Butt, R.L.; Volkoff, H. Gut microbiota and energy homeostasis in fish. Front. Endocrinol. (Lausanne) 2019, 10, 6-8. [CrossRef] [PubMed]

28. Sullam, K.E.; Essinger, S.D.; Lozupone, C.A.; O'Connor, M.P.; Rosen, G.L.; Knight, R.; Kilham, S.S.; Russell, J.A. Environmental and ecological factors that shape the gut bacterial communities of fish: A meta-analysis. Mol. Ecol. 2012, 21, 3363-3378. [CrossRef] [PubMed]

29. de Bruijn, I.; Liu, Y.; Wiegertjes, G.F.; Raaijmakers, J.M. Exploring fish microbial communities to mitigate emerging diseases in aquaculture. FEMS Microbiol. Ecol. 2018, 94, 1-12. [CrossRef]

30. Clements, K.D.; Angert, E.R.; Montgomery, W.L.; Choat, J.H. Intestinal microbiota in fishes: What's known and what's not. Mol. Ecol. 2014, 23, 1891-1898. [CrossRef] [PubMed]

31. Neave, M.J.; Apprill, A.; Aeby, G.; Miyake, S.; Voolstra, C.R. Microbial Communities of Red Sea Coral Reefs; Springer International Publishing: Cham, Switzerland, 2019; pp. 53-68. [CrossRef]

32. Amato, K.R.; Yeoman, C.J.; Kent, A.; Righini, N.; Carbonero, F.; Estrada, A.; Rex Gaskins, H.; Stumpf, R.M.; Yildirim, S.; Torralba, M.; et al. Habitat degradation impacts black howler monkey (Alouatta pigra) gastrointestinal microbiomes. ISME J. 2013, 7, 1344-1353. [CrossRef]

33. Kohl, K.D.; Amaya, J.; Passement, C.A.; Dearing, M.D.; Mccue, M.D. Unique and shared responses of the gut microbiota to prolonged fasting: A comparative study across five classes of vertebrate hosts. FEMS Microbiol. Ecol. 2014, 90, 883-894. [CrossRef] [PubMed] 
34. Borbón-García, A.; Reyes, A.; Vives-Flórez, M.; Caballero, S. Captivity shapes the gut microbiota of Andean bears: Insights into health surveillance. Front. Microbiol. 2017, 8, 1-12. [CrossRef] [PubMed]

35. Clayton, J.B.; Vangay, P.; Huang, H.; Ward, T.; Hillmann, B.M.; Al-Ghalith, G.A.; Travis, D.A.; Long, H.T.; Van Tuan, B.; Van Minh, V.; et al. Captivity humanizes the primate microbiome. Proc. Natl. Acad. Sci. USA 2016, 113, 10376-10381. [CrossRef]

36. Schmidt, E.; Mykytczuk, N.; Schulte-Hostedde, A.I. Effects of the captive and wild environment on diversity of the gut microbiome of deer mice (Peromyscus maniculatus). ISME J. 2019, 13, 1293-1305. [CrossRef]

37. Gudka, M.; Obura, D.; Mbugua, J.; Ahamada, S.; Kloiber, U.; Holter, T. Participatory reporting of the 2016 bleaching event in the Western Indian Ocean. Coral Reefs 2020, 39. [CrossRef]

38. Faure, G.; Guillaume, M.; Payri, C.; Thomassin, B.; Vanpraet, M.; Vasseur, P. Massive bleaching and death of corals in the Mayotte Reef ecosystem (SW Indian-Ocean). Comptes Rendus l'académie des Sci. Série III-Sciences la vie-Life Sci. 1984, $299,637-642$.

39. Wilkinson, C.; Lindén, O.; Cesar, H.; Hodgson, G.; Rubens, J.; Strong, A.E. Ecological and socioeconomic impacts of 1998 coral mortality in the Indian Ocean: An ENSO impact and a warning of future change? Ambio 1999, 28, 188-196.

40. Wilson, S.K.; Robinson, J.P.W.; Chong-Seng, K.; Robinson, J.; Graham, N.A.J. Boom and bust of keystone structure on coral reefs. Coral Reefs 2019, 38, 625-635. [CrossRef]

41. Graham, N.A.J.; Wilson, S.K.; Jennings, S.; Polunin, N.V.C.; Bijoux, J.P.; Robinson, J. Dynamic fragility of oceanic coral reef ecosystems. Proc. Natl. Acad. Sci. USA 2006, 103, 8425-8429. [CrossRef] [PubMed]

42. Robinson, J.P.W.; Wilson, S.K.; Jennings, S.; Graham, N.A.J. Thermal stress induces persistently altered coral reef fish assemblages. Glob. Chang. Biol. 2019, 25, 2739-2750. [CrossRef]

43. Clements, K.D.; Pasch, I.B.Y.; Moran, D.; Turner, S.J. Clostridia dominate $16 \mathrm{~S}$ rRNA gene libraries prepared from the hindgut of temperate marine herbivorous fishes. Mar. Biol. 2007, 150, 1431-1440. [CrossRef]

44. Taquet, M.; Delinguer, A. Poissons de l'Océan Indien et de la Mer Rouge; Quae: Versailles, 2007; ISBN 978-2-7592-0045-0.

45. Mouillot, D.; Villéger, S.; Parravicini, V.; Kulbicki, M.; Arias-González, J.E.; Bender, M.; Chabanet, P.; Floeter, S.R.; Friedlander, A.; Vigliola, L.; et al. Functional over-redundancy and high functional vulnerability in global fish faunas on tropical reefs. Proc. Natl. Acad. Sci. USA 2014, 111, 13757-13762. [CrossRef]

46. Clements, K.D.; German, D.P.; Piché, J.; Tribollet, A.; Choat, J.H. Integrating ecological roles and trophic diversification on coral reefs: Multiple lines of evidence identify parrotfishes as microphages. Biol. J. Linn. Soc. 2017, 120, 729-751. [CrossRef]

47. McArdle, B.H.; Anderson, M.J. Fitting multivariate models to community data: A comment on distance-based redundancy analysis. Ecology 2001, 82, 290-297. [CrossRef]

48. Oksanen, J.; Blanchet, F.G.; Michael, F.; Kindt, R.; Legendre, P.; McGlinn, D.; Minchin, P.R.; O’Hara, R.B.; Simpson, G.L.; Peter, S.; et al. Vegan: Community Ecology Package. 2019. Available online: inecol.mx (accessed on 9 August 2021).

49. Parada, A.E.; Needham, D.M.; Fuhrman, J.A. Every base matters: Assessing small subunit rRNA primers for marine microbiomes with mock communities, time series and global field samples. Environ. Microbiol. 2016, 18, 1403-1414. [CrossRef] [PubMed]

50. R Core Team R. A language and environment for statistical computing. 2020. Available online: r-project.org (accessed on 9 August 2021).

51. Callahan, B.J.; McMurdie, P.J.; Rosen, M.J.; Han, A.W.; Johnson, A.J.A.; Holmes, S.P. DADA2: High-resolution sample inference from Illumina amplicon data. Nat. Methods 2016, 13, 581-583. [CrossRef]

52. Glassman, S.I.; Martiny, J.B.H. Broadscale Ecological Patterns Are Robust to Use of Exact. mSphere 2018, 3, e00148-18. [CrossRef] [PubMed]

53. Quast, C.; Pruesse, E.; Yilmaz, P.; Gerken, J.; Schweer, T.; Yarza, P.; Peplies, J.; Glöckner, F.O. The SILVA ribosomal RNA gene database project: Improved data processing and web-based tools. Nucleic Acids Res. 2013, 41, 590-596. [CrossRef]

54. McMurdie, P.J.; Holmes, S. Phyloseq: An R Package for Reproducible Interactive Analysis and Graphics of Microbiome Census Data. PLoS ONE 2013, 8, e61217. [CrossRef] [PubMed]

55. Salter, S.J.; Cox, M.J.; Turek, E.M.; Calus, S.T.; Cookson, W.O.; Moffatt, M.F.; Turner, P.; Parkhill, J.; Loman, N.J.; Walker, A.W. Reagent and laboratory contamination can critically impact sequence-based microbiome analyses. BMC Biol. $2014,12,87$. [CrossRef]

56. Cariveau, D.P.; Elijah Powell, J.; Koch, H.; Winfree, R.; Moran, N.A. Variation in gut microbial communities and its association with pathogen infection in wild bumble bees (Bombus). ISME J. 2014, 8, 2369-2379. [CrossRef]

57. Madhusoodanan, J. News Feature: Do hosts and their microbes evolve as a unit? Proc. Natl. Acad. Sci. USA 2019, 116, 14391-14394. [CrossRef]

58. Berg, R. The indigenous gastrointestinal microflora. Trends Microbiol. 1996, 4, 430-435. [CrossRef]

59. Martinson, V.G.; Danforth, B.N.; Minckley, R.L.; Rueppell, O.; Tingek, S.; Moran, N.A. A simple and distinctive microbiota associated with honey bees and bumble bees. Mol. Ecol. 2011, 20, 619-628. [CrossRef]

60. Koch, H.; Abrol, D.P.; Li, J.; Schmid-Hempel, P. Diversity and evolutionary patterns of bacterial gut associates of corbiculate bees. Mol. Ecol. 2013, 22, 2028-2044. [CrossRef]

61. Magurran, A.E.; Henderson, P.A. Explaining the excess of rare species in natural species abundance distributions. Nature 2003, 422, 714-716. [CrossRef] [PubMed]

62. Krebs, C.J. Ecological Methodology; Pearson; Addison-Wesley Educational Publishers: Menlo Park, 1999 ; ISBN 9780321021731. 
63. Schloss, P.D.; Westcott, S.L.; Ryabin, T.; Hall, J.R.; Hartmann, M.; Hollister, E.B.; Lesniewski, R.A.; Oakley, B.B.; Parks, D.H.; Robinson, C.J.; et al. Introducing mothur: Open-source, platform-independent, community-supported software for describing and comparing microbial communities. Appl. Environ. Microbiol. 2009, 75, 7537-7541. [CrossRef] [PubMed]

64. Ludwig, W.; Strunk, O.; Westram, R.; Richter, L.; Meier, H.; Yadhukumar, A.; Buchner, A.; Lai, T.; Steppi, S.; Jacob, G.; et al. ARB: A software environment for sequence data. Nucleic Acids Res. 2004, 32, 1363-1371. [CrossRef]

65. Letunic, I.; Bork, P. Interactive tree of life (iTOL) v3: An online tool for the display and annotation of phylogenetic and other trees. Nucleic Acids Res. 2016, 44, W242-W245. [CrossRef] [PubMed]

66. Chao, A.; Lee, S.-M.; Chen, T.-C. A generalized Good's nonparametric coverage estimator. Chin. J. Math. 1988, 16, 189-199.

67. Jost, L. Entropy and diversity. Oikos 2006, 113, 363-375. [CrossRef]

68. Wemheuer, F.; Taylor, J.A.; Daniel, R.; Johnston, E.; Meinicke, P.; Thomas, T.; Wemheuer, B. Tax4Fun2: Prediction of habitat-specific functional profiles and functional redundancy based on $16 \mathrm{~S}$ rRNA gene sequences. Environ. Microbiome 2020, 15, 11. [CrossRef]

69. Segata, N.; Izard, J.; Waldron, L.; Gevers, D.; Miropolsky, L.; Garrett, W.S.; Huttenhower, C. Metagenomic biomarker discovery and explanation. Genome Biol. 2011, 12, R60. [CrossRef]

70. Chong-Seng, K.M.; Mannering, T.D.; Pratchett, M.S.; Bellwood, D.R.; Graham, N.A.J. The influence of coral reef benthic condition on associated fish assemblages. PLOS ONE 2012, 7, e42167. [CrossRef]

71. Graham, N.A.J.; Robinson, J.P.W.; Smith, S.E.; Govinden, R.; Gendron, G.; Wilson, S.K. Changing role of coral reef marine reserves in a warming climate. Nat. Commun. 2020, 11, 2000. [CrossRef] [PubMed]

72. Silveira, C.B.; Cavalcanti, G.S.; Walter, J.M.; Silva-Lima, A.W.; Dinsdale, E.A.; Bourne, D.G.; Thompson, C.C.; Thompson, F.L. Microbial processes driving coral reef organic carbon flow. FEMS Microbiol. Rev. 2017, 41, 575-595. [CrossRef]

73. McDole, T.; Nulton, J.; Barott, K.L.; Felts, B.; Hand, C.; Hatay, M.; Lee, H.; Nadon, M.O.; Nosrat, B.; Salamon, P.; et al. Assessing Coral Reefs on a Pacific-Wide Scale Using the Microbialization Score. PLoS ONE 2012, 7, e43233. [CrossRef]

74. Meirelles, P.M.; Amado-Filho, G.M.; Pereira-Filho, G.H.; Pinheiro, H.T.; De Moura, R.L.; Joyeux, J.C.; Mazzei, E.F.; Bastos, A.C.; Edwards, R.A.; Dinsdale, E.; et al. Baseline assessment of mesophotic reefs of the Vitória-Trindade Seamount Chain based on water quality, microbial diversity, benthic cover and fish biomass data. PLoS ONE 2015, 10, e0130084. [CrossRef]

75. Haas, A.F.; Fairoz, M.F.M.; Kelly, L.W.; Nelson, C.E.; Dinsdale, E.A.; Edwards, R.A.; Giles, S.; Hatay, M.; Hisakawa, N.; Knowles, B.; et al. Global microbialization of coral reefs. Nat. Microbiol. 2016, 1, 16042. [CrossRef]

76. Roach, T.N.F.; Abieri, M.L.; George, E.E.; Knowles, B.; Naliboff, D.S.; Smurthwaite, C.A.; Kelly, L.W.; Haas, A.F.; Rohwer, F.L. Microbial bioenergetics of coral-algal interactions. PeerJ 2017, 2017, 1-19. [CrossRef] [PubMed]

77. Haas, A.F.; Nelson, C.E.; Kelly, L.W.; Carlson, C.A.; Rohwer, F.; Leichter, J.J.; Wyatt, A.; Smith, J.E. Effects of coral reef benthic primary producers on dissolved organic carbon and microbial activity. PLoS ONE 2011, 6, e27973. [CrossRef] [PubMed]

78. Vega Thurber, R.; Burkepile, D.E.; Correa, A.M.S.; Thurber, A.R.; Shantz, A.A.; Welsh, R.; Pritchard, C.; Rosales, S. Macroalgae Decrease Growth and Alter Microbial Community Structure of the Reef-Building Coral, Porites astreoides. PLoS ONE 2012, 7, e44246. [CrossRef]

79. Munday, P.L.; Jones, G.P.; Pratchett, M.S.; Williams, A.J. Climate change and the future for coral reef fishes. Fish Fish. 2008, 9, 261-285. [CrossRef]

80. Munday, P.; Jones, G.; Caley, M. Habitat specialisation and the distribution and abundance of coral-dwelling gobies. Mar. Ecol. Prog. Ser. 1997, 152, 227-239. [CrossRef]

81. Gardiner, N.; Jones, G. Habitat specialisation and overlap in a guild of coral reef cardinalfishes (Apogonidae). Mar. Ecol. Prog. Ser. 2005, 305, 163-175. [CrossRef]

82. Pratchett, M.S. Dietary overlap among coral-feeding butterflyfishes (Chaetodontidae) at Lizard Island, northern Great Barrier Reef. Mar. Biol. 2005, 148, 373-382. [CrossRef]

83. Bellwood, D.R.; Hughes, T.P.; Hoey, A.S. Sleeping Functional Group Drives Coral-Reef Recovery. Curr. Biol. 2006, 16, 2434-2439. [CrossRef] [PubMed]

84. Feary, D.; Almany, G.; Jones, G.; McCormick, M. Coral degradation and the structure of tropical reef fish communities. Mar. Ecol. Prog. Ser. 2007, 333, 243-248. [CrossRef]

85. Silveira, C.B.; Silva-Lima, A.W.; Francini-Filho, R.B.; Marques, J.S.M.; Almeida, M.G.; Thompson, C.C.; Rezende, C.E.; Paranhos, R.; Moura, R.L.; Salomon, P.S.; et al. Microbial and sponge loops modify fish production in phase-shifting coral reefs. Environ. Microbiol. 2015, 17, 3832-3846. [CrossRef] [PubMed]

86. Alexander, B.E.; Liebrand, K.; Osinga, R.; van der Geest, H.G.; Admiraal, W.; Cleutjens, J.P.M.; Schutte, B.; Verheyen, F.; Ribes, M.; van Loon, E.; et al. Cell Turnover and Detritus Production in Marine Sponges from Tropical and Temperate Benthic Ecosystems. PLoS ONE 2014, 9, e109486. [CrossRef] [PubMed]

87. Mueller, B.; de Goeij, J.M.; Vermeij, M.J.A.; Mulders, Y.; van der Ent, E.; Ribes, M.; van Duyl, F.C. Natural Diet of Coral-Excavating Sponges Consists Mainly of Dissolved Organic Carbon (DOC). PLoS ONE 2014, 9, e90152. [CrossRef] [PubMed]

88. Smith, J.E.; Shaw, M.; Edwards, R.A.; Obura, D.; Pantos, O.; Sala, E.; Sandin, S.A.; Smriga, S.; Hatay, M.; Rohwer, F.L. Indirect effects of algae on coral: Algae-mediated, microbe-induced coral mortality. Ecol. Lett. 2006, 9, 835-845. [CrossRef]

89. Barott, K.L.; Rohwer, F.L. Unseen players shape benthic competition on coral reefs. Trends Microbiol. 2012, 20, 621-628. [CrossRef]

90. Morrow, K.M.; Ritson-Williams, R.; Ross, C.; Liles, M.R.; Paul, V.J. Macroalgal Extracts Induce Bacterial Assemblage Shifts and Sublethal Tissue Stress in Caribbean Corals. PLoS ONE 2012, 7, e44859. [CrossRef] [PubMed] 
91. Beatty, D.; Clements, C.; Stewart, F.; Hay, M. Intergenerational effects of macroalgae on a reef coral: Major declines in larval survival but subtle changes in microbiomes. Mar. Ecol. Prog. Ser. 2018, 589, 97-114. [CrossRef]

92. Nelson, C.E.; Goldberg, S.J.; Wegley Kelly, L.; Haas, A.F.; Smith, J.E.; Rohwer, F.; Carlson, C.A. Coral and macroalgal exudates vary in neutral sugar composition and differentially enrich reef bacterioplankton lineages. ISME J. 2013, 7, 962-979. [CrossRef]

93. Meirelles, P.M.; Soares, A.C.; Oliveira, L.; Leomil, L.; Appolinario, L.R.; Francini-Filho, R.B.; De Moura, R.L.; De Barros Almeida, R.T.; Salomon, P.S.; Amado-Filho, G.M.; et al. Metagenomics of coral reefs under phase shift and high hydrodynamics. Front. Microbiol. 2018, 9, 1-13. [CrossRef] [PubMed]

94. Aiken, D.E.; Waddy, S.L. Aquaculture. In Biology of the Lobster; Elsevier: Amsterdam, The Netherlands, $1995 ;$ pp. 153-175.

95. Ghanbari, M.; Kneifel, W.; Domig, K.J. A new view of the fish gut microbiome: Advances from next-generation sequencing. Aquaculture 2015, 448, 464-475. [CrossRef]

96. Egerton, S.; Culloty, S.; Whooley, J.; Stanton, C.; Ross, R.P. The gut microbiota of marine fish. Front. Microbiol. 2018,9 , 873. [CrossRef]

97. Barelli, C.; Albanese, D.; Donati, C.; Pindo, M.; Dallago, C.; Rovero, F.; Cavalieri, D.; Michael Tuohy, K.; Christine Hauffe, H.; De Filippo, C. Habitat fragmentation is associated to gut microbiota diversity of an endangered primate: Implications for conservation. Sci. Rep. 2015, 5, 14862. [CrossRef]

98. Hayden, B.; Palomares, M.L.D.; Smith, B.E.; Poelen, J.H. Biological and environmental drivers of trophic ecology in marine fishes-a global perspective. Sci. Rep. 2019, 9, 11415. [CrossRef] [PubMed]

99. Green, A.L.; Maypa, A.P.; Almany, G.R.; Rhodes, K.L.; Weeks, R.; Abesamis, R.A.; Gleason, M.G.; Mumby, P.J.; White, A.T. Larval dispersal and movement patterns of coral reef fishes, and implications for marine reserve network design. Biol. Rev. 2015, 90, 1215-1247. [CrossRef]

100. Zaneveld, J.R.; McMinds, R.; Thurber, R.V. Stress and stability: Applying the Anna Karenina principle to animal microbiomes. Nat. Microbiol. 2017, 2, 17121. [CrossRef] [PubMed]

101. Van Soest, J.P. Nutritional Ecology of the Ruminant; Cornell University Press: Ithaca, NY, USA, 1994.

102. Jones, J.; DiBattista, J.D.; Stat, M.; Bunce, M.; Boyce, M.C.; Fairclough, D.V.; Travers, M.J.; Huggett, M.J. The microbiome of the gastrointestinal tract of a range-shifting marine herbivorous fish. Front. Microbiol. 2018, 9, 2000. [CrossRef] [PubMed]

103. Zhang, X.; Wu, H.; Li, Z.; Li, Y.; Wang, S.; Zhu, D.; Wen, X.; Li, S. Effects of dietary supplementation of Ulva pertusa and non-starch polysaccharide enzymes on gut microbiota of Siganus canaliculatus. J. Oceanol. Limnol. 2018, 36, 438-449. [CrossRef]

104. Miller, D.A.; Suen, G.; Bruce, D.; Copeland, A.; Cheng, J.-F.; Detter, C.; Goodwin, L.A.; Han, C.S.; Hauser, L.J.; Land, M.L.; et al. Complete Genome Sequence of the Cellulose-Degrading Bacterium Cellulosilyticum lentocellum. J. Bacteriol. 2011, 193, 2357-2358. [CrossRef]

105. Mountfort, D.O.; Campbell, J.; Clements, K.D. Hindgut Fermentation in Three Species of Marine Herbivorous Fish. Appl. Environ. Microbiol. 2002, 68, 1374-1380. [CrossRef]

106. Clements, K.D.; Choat, J.H. Fermentation in Tropical Marine Herbivorous Fishes. Physiol. Zool. 1995, 68, 355-378. [CrossRef] 